\title{
Applications and limitations of thermobarometry in migmatites and granulites using as an example rocks of the Araçuaí Orogen in southern Bahia, including a discussion on the tectonic meaning of the current results
}

\author{
Aplicações e limitações da termobarometria em migmatitos e \\ granulitos usando como exemplo as rochas do Orógeno Araçuaí no Sul \\ da Bahia, incluindo discussão do significado tectônico dos resultados

\section{Renato Moraes ${ }^{1 *}$, Christian Nicollet ${ }^{2}$, Johildo Salomão Figueiredo Barbosa ${ }^{3}$, Reinhardt Adolfo Fuck ${ }^{4}$, Antônio Rabelo Sampaio ${ }^{5}$}

\begin{abstract}
In southern Bahia, there are outcrops of migmatites and granulites in the Jequitinhonha Complex, which is part of the northern portion of the Araçuaí Orogen. Migmatites (garnet-cordierite diatexite) dominate the metamorphic rocks and host lenses and layers of felsic garnet granulite. The conditions of temperature and pressure of metamorphism were calculated using conventional thermobarometry and the software THERMOCALC. Values around $850{ }^{\circ} \mathrm{C}$ and $7 \mathrm{kbar}$ were obtained with THERMOCALC. The calculations for the garnet-cordierite diatexite were made considering $a_{\mathrm{H} 2 \mathrm{O}}$ equal to 1 , but the best results of calculations for the granulites are obtained with $a_{\mathrm{H} 2 \mathrm{O}}$ values of 0.3 . Pressure values obtained with GAPES resulted in consistent values with THERMOCALC, but the pair garnet-orthopyroxene always produces low values for temperature and high ones for pressure. The results are consistent with the presence of the pair garnet and cordierite in diatexite and orthopyroxene in felsic granulite. From the tectonic point of view, the setting in which metamorphism of these rocks occurred requires high heat flow with a thermal anomaly in mid continental crust, as indicated by values of $7 \mathrm{kbar}$. Recent studies have favored the closure of a back-arc basin for this tectonic setting, but it does not solve the problem that the time span between metamorphic peak and the end of granite intrusions, involving large bodies of charnockite, is more than 80 million years.
\end{abstract}

RESUMO: No sul da Babia ocorrem migmatitos e granulitos do Complexo Jequitinhonha, porção norte do Orógeno Araçuaí. Os migmatitos (granada-cordierita diatexitos) dominam as rochas metamórficas e incluem lentes e camadas de granada granulito félsico. As condiçöes de temperatura e pressáo do metamorfismo foram calculadas com termobarometria convencional e THERMOCALC. Valores em torno de $850^{\circ} \mathrm{C}$ e 7 kbar foram obtidos com THERMOCALC, sendo que para o diatexito os cálculos foram feitos considerando $a_{\mathrm{H} 2 \mathrm{O}}$ igual a 1 , mas os melhores resultados de cálculos para o granulito são feitos com valores de $a_{H 2 O}$ igual a 0,3. Os cálculos de pressão obtidos com GAPES resultam em valores concordantes com o THERMOCALC, mas o par granada-ortopiroxênio sempre produz valores baixos para temperatura e elevados para pressáo. Os resultados são condizentes com a presença do par granada e cordierita no diatexito e ortopiroxênio no granulito félsico. Do ponto de vista tectônico o ambiente em que o metamorfismo dessas rochas ocorreu necessita de alto fluxo de calor com anomalia térmica em regióes médias da crosta, considerando os valores de 7 kbar. Trabalhos recentes têm favorecido o fechamento de bacia back-arc para esse ambiente, mas isso náo resolve o problema de que entre a época do pico metamórfico e a granitogênese final, envolvendo grandes corpos de charnockito, existe intervalo de mais de 80 milhöes de anos. O modelo de comutação tectônica

\footnotetext{
${ }^{1}$ Instituto de Geociências - Departamento de Mineralogia e Geotectônica, Universidade de São Paulo - USP, E-mail: rmoraes@usp.br

2Université Blaise Pascal - Département des Sciences de la Terre Clermont-Ferrand. E-mail: C.Nicollet@opgc.univ-bpclermont.fr ${ }^{3}$ Instituto de Geociências - Departamento de Geoquímica Salvador, Universidade Federal da Bahia - UFBA, E-mail: johildo@cpgg.ufba.br ${ }^{4}$ Instituto de Geociências Brasília, Universidade de Brasília - UnB,E-mail: reinhardt@unb.br

${ }^{5}$ Companhia de Pesquisa de Recursos Minerais - CPRM, Salvador, BA. E-mail: rabelo49@gmail.com

*Corresponding author

Manuscript ID: 20150026. Received: 08/20/2015. Approved: 09/08/2015
} 
The model of tectonic switching is suggested here as it can explain the maintenance of high temperatures for a more extended interval of time.

KEYWORDS: Araçuaí Orogen; Granulite; Migmatite; Thermobarometry.

\section{INTRODUCTION}

To calculate the conditions of pressure and temperature for rocks that underwent granulite facies metamorphism should be simple and straightforward, as the formation conditions overlap those used in most experiments to calibrate thermometers and barometers. However, several factors linked to the genesis of granulites and migmatites contribute negatively to make this task simple and easy. After the metamorphic peak temperature is achieved, often greater than $800^{\circ} \mathrm{C}$, granulites and migmatites cool down slowly in the middle to lower portions of the continental crust, a situation that leads to their re-equilibration. Furthermore, the presence of a melt phase is common in granulite facies conditions and can enhance the rate of diffusion or even destroy anhydrous metamorphic peak mineralogy during cooling (Moraes et al. 2002; White \& Powell 2002, 2010). For the effective calculation of $P-T$ conditions, either corrections on mineral compositions or thermodynamic modeling must be done. The loss of simplicity makes the task complex, challenging, attractive and, particularly, an interesting subject.

To illustrate some of the problems related to the $P-T$ calculation in migmatites and granulites, rocks of the Araçuaí Orogen, in southern Bahia, will be used as an example. Once the results are obtained, an evaluation of their geological, metamorphic and tectonic meaning is undertaken.

\section{Thermobarometry applied to granulites and migmatites: problems and restrictions}

In continental crust granulite facies metamorphism, in addition to recrystallization of the protolith, conditions may involve significant amount of partial melting. The percentage of the partial melting depends on the rock fertility, with practically zero for anhydrous basalt, increasing to amphibolite, granite, greywacke and pelite. The process involves biotite or hornblende dehydration melting reactions, at temperatures above $800^{\circ} \mathrm{C}$, producing $\mathrm{H}_{2} \mathrm{O}$ unsaturated silicate liquid and a solid residue, rich in peritectic phases (Fyfe 1973; Thompson 1982; Hartel \& Pattison 1996; Vielzeuf \& Schmidt 2001; White \& Powell 2002; Johnson et al. 2008). Among the most common peritectic minerals are garnet, ortho- and clinopyroxene, minerals used in thermobarometry of granulite facies rocks. Slow cooling and the coexistence of the granulite residue with silicate melt are responsible for most of the problems related to the application of thermobarometric methods to migmatites (tectonic switching) é sugerido para explicar a manutenção de temperaturas elevadas durante intervalo de tempo tão prolongado.

PALAVRAS-CHAVE: Granulito; Migmatito; Orógeno Araçuaí;

Termobarometria.

and granulites. The direct calculation of the metamorphic peak conditions can be hampered when it is followed by a slow cooling stage, which facilitates continuous exchange of $\mathrm{Fe}, \mathrm{Mg}$, $\mathrm{Ca}$ and even $\mathrm{Al}$, between garnet and pyroxenes until low temperatures, modifying significantly their compositions (Frost $\&$ Chacko 1988; Harley 1989, 2008; Fitzsimons \& Harley 1994; Pattison \& Bégin 1994; Pattison et al. 2003). As these minerals participate in a significant part of thermometers and barometers of granulite facies, it is necessary to evaluate the extent of chemical changes to proceed with the methods of correction of the mineral compositions. The changes are more extensive when pyroxene grains are in direct contact with garnet, or when garnet is surrounded by biotite, generating the worst results in thermobarometry (Spear \& Florence 1992). Major adjustments in mineral compositions might be avoided when garnet and pyroxene grains are separated by quartz or plagioclase, which inhibit re-equilibration of $\mathrm{Fe}$ and $\mathrm{Mg}$ (Fitzsimons \& Harley 1994; Pattison \& Bégin 1994).

For the recovery of the metamorphic peak mineral compositions, there are some developed methods (Fitzsimons \& Harley 1994; Pattison \& Bégin 1994; Moraes \& Fuck 2000; Pattison et al 2003), and most are based on experiments carried out to calibrate both barometers (Harley \& Green 1982; Harley 1984b) and a thermometer (Harley 1984a), involving the garnet-orthopyroxene pair. The calibration of the Harley and Green (1982) barometer is independent of the Fe/Mg ratio of minerals, but it is not the case with the one produced by Harley (1984b). Therefore, it is possible to calculate pressure with the aid of both calibrations, and by changing the Fe/Mg ratio of orthopyroxene and garnet, the two calibrations may provide the same pressure. Starting from the adjusted compositions, the temperature of the metamorphic peak is calculated by using the orthopyroxene-garnet thermometer (Fitzsimons $\&$ Harley 1994; Pattison \& Bégin 1994). A variant of this method also takes into account the modal proportion of minerals to limit and control the corrections made (Pattison et al. 2003).

The coexistence of a silicate melt and granulite residue may be responsible for changes in post-peak metamorphic rock mineral assemblage, involving consumption and production of mineral phases. Also, the presence of melt facilitates the diffusion of elements between minerals, increasing the efficacy in the chemical re-equilibrium during cooling, which may promote profound changes in their composition, thwarting successful thermobarometric calculations. If the melt is not segregated from granulite residue before cooling, the minerals of metamorphic peak may 
react with it and suffer total or partial consumption that can even erase the evidence of granulite facies in the rock (Powell \& Downes 1990; Moraes et al. 2002; White \& Powell 2002, 2010). Full preservation of the granulite facies mineral assemblage is achieved by the removal of most produced melt (Moraes et al. 2002; White \& Powell 2002). Additional problems may happen due to crystallization of entrapped melt within the residue, which generates new minerals not present during the metamorphic peak, for example, plagioclase, biotite and ilmenite, which if used in thermobarometric calculations will generate values of temperature and pressure without any geological significance.

Modern softwares use internally consistent thermodynamic data sets for thermobarometric calculations and other petrological tasks, such as TWQEEU (Berman 1988) and THERMOCALC (Holland \& Powell 1998, 2011). Here, the thermobarometric calculations are based on a group of linearly independent reactions that use all thermodynamic information of metamorphic peak mineral assemblages; consequently, the results produced are robust (Powell \& Holland 1994). If it is possible to have the bulk composition of the protolith before granulite facies metamorphism and partial melting took place, for example, by analyzing an amphibolite facies regional equivalent, it is possible to calculate pseudosections and, through them, to make a model of metamorphism and partial melting processes (White \& Powell 2002; Powell et al. 2005; Baldwin et al. 2005). The beauty of pseudosections is also its doom, because its calculation is based on the rock bulk composition, but in the case of migmatites and granulites, which involved partial melting and segregation of its melt phase, original rock bulk composition is lost, making it difficult or impossible to use the method for a precise thermobarometry.

\section{Geological Setting of the Araçuaí Orogen}

The Araçuaí Belt was defined as the fold belt formed during the Brasiliano Orogeny, which limits the south and southeast borders of the São Francisco Craton in Minas Gerais and Bahia (Almeida 1977). It is part of the Mantiqueira Province (Almeida et al. 1977, 1981), or the northern portion of the Mantiqueira Orogenic System (Heilbron et al. 2004), or even the external portion of the Brazilian side of the Araçuaí-West Congo Orogen (Trompette 1994; Pedrosa-Soares \& Wiedemann-Leonardos 2000; Pedrosa-Soares et al. 2001, 2007, Fig. 1). The last concept is adopted here for further discussions.

As the geological knowledge evolved, correlations between Brazilian and African counterparts were done, especially between Araçuaí and West Congo fold belts and São Francisco and Congo cratons (e.g. Brito-Neves \& Cordani 1991, Trompette 1994). It was then recognized that rocks in the once adjacent continents represent different portions of a whole orogen, the Araçuai-WestCongo Orogen (Pedrosa-Soares \& Noce 1998; Pedrosa-Soares \& Wiedemann-Leonardos 2000; Pedrosa-Soares et al. 2001, 2007), which is referred here, for simplicity, as the Araçuaí Orogen. For details and definitions of the orogen portions, equally its stratigraphy, tectonic units and magmatic suites, the reader must access recent in-depth reviews (Alkmin et al. 2007; Noce et al. 2007; Pedrosa-Soares et al. 2007, 2008; Pedrosa-Soares \& Alkmin 2011; Gradim et al., 2014).

The orogen was developed from the end of Neoproterozoic until Cambrian times (Fig. 1). The continental rift stage of the precursor basin is represented by, at least, six events of rifting and anorogenic magmatism. The youngest events are recorded by rocks of the basal portion of the Macaúbas Group, mafic dikes of the Pedro Lessa Suite and anorogenic intraplate granites of the Salto da Divisa Suite, all of these rocks being older than $870 \mathrm{Ma}$ (Pedrosa-Soares et al. 2007; Pedrosa-Soares \& Alkmin 2011). The passive margin rocks are represented by mid to upper formations of the Macaúbas Group, including mafic-ultramafic rocks, pelites and cherts, part of an ophiolite complex that represents the oceanic portion of this basin (Pedrosa-Soares et al. 1992, 1998, 2001, 2008, Aracema et al. 2000). Zircon grains of plagiogranite, associated with the mafic oceanic rocks, yielded $660 \pm 29 \mathrm{Ma}$, age considered as the time oceanic crust was formed (Queiroga et al. 2007). The pelites that derived migmatites of the Jequitinhonha Complex (Almeida \& Litwinski 1984) may as well be part of this passive margin (Pedrosa-Soares \& Wiedemann-Leonardos 2000, Sampaio et al. 2004, Heilbron et al. 2004, Pedrosa- Soares et al. 2008).

Extensive granite magmatism is recognized, ranging from arc-related, representing a pre-collisional stage ( $c a .630$ $580 \mathrm{Ma}$ ), to sin-collisional (ca. $580-560 \mathrm{Ma}$ ), up to post-collisional (ca. $530-490 \mathrm{Ma}$ ). Structural relationships, as well as petrographic types, geochemistry signatures and isotopic ages are used to define this evolution and separate the bodies in five suites (e.g. Pedrosa-Soares \& Wiedemann-Leonardos 2000, Pedrosa-Soares et al. 2001, 2008, Silva et al. 2005). The G1 suite defines the pre-collisional stage and comprises deformed calc-alkaline tonalite and granodiorite bodies with ages that span from 630 to $585 \mathrm{Ma}$. S-type granites, mostly deformed and bearing cordierite and garnet are denominated as G2 and G3 suites; they define the sin-collisional stage and present ages between 585 and $535 \mathrm{Ma}$. The post-collision stage is marked by topographic highs, as the sugar-loafs bodies of G4 and G5 suites, with ages that span from 520 to $490 \mathrm{Ma}$ (Siga Jr. 1986; Pedrosa-Soares \& Wiedemann-Leonardos, 2000; PedrosaSoares et al. 2001). These granite bodies were emplaced mainly into migmatites of the Jequitinhonha Complex and rocks of the Macaúbas Group and are represented, respectively, by two mica S-type granite and charnockite bodies, the last ones with marked mantle-derived signature (Pedrosa-Soares \& WiedemannLeonardos 2000; Pedrosa-Soares et al. 2007).

Two different units of the Araçuaí Orogen are constituted of migmatites derived from pelites, the Nova Venécia Complex, 
which represents rocks deposited and metamorphosed in the back-arc basin (Gradim et al. 2014), and the Jequitinhonha Complex (Almeida \& Litwinski 1984; Sampaio et al. 2004), whose protoliths were deposited in distal passive margin (Pedrosa-Soares et al. 2007; Gonçalves-Dias et al. 2011). The first geochronological data for these rocks was a $\mathrm{Rb}-\mathrm{Sr}$ reference isochron using samples from both units. The results obtained indicate that the metamorphic event affecting these units occurred at $550 \pm 80 \mathrm{Ma}$ (Cordani 1973). Later on, an interval for the age of metamorphism between 660 and $570 \mathrm{Ma}$, based on Rb-Sr isochrons, was determined for rocks of the Jequitinhonha Complex, with cooling ages between 540 and $480 \mathrm{Ma}$ (Siga Jr. 1986). Initial $\mathrm{Sr}^{87} / \mathrm{Sr}^{86}$ ratios indicate crustal sources of Paleoproterozoic and Neoproterozoic ages (Siga Jr. 1986) for the Jequitinhonha Complex. Dating of detrital zircon grains extracted from the Nova Venécia Complex have yielded ages spreading between 630 and 2100 (Noce et al. 2004). The newer acquired data set of detrital zircon from rocks of the Jequitinhonha Complex resulted in ages between 960 and $2540 \mathrm{Ma}$, with the youngest grains dated at $898 \pm 8 \mathrm{Ma}$, considered to be the maximum age of deposition of this unit, what makes the unit chrono-correlated to the upper portion of the Macaúbas Group (Gonçalves-Dias et al. 2011).

$P-T$ data of metamorphism and partial melting of migmatites of the Jequitinhonha Complex are scarce. Temperature is calculated between 715 and $790^{\circ} \mathrm{C}$ by using garnet-cordierite and garnet-biotite pairs (Uhlein et al. 1998). Crystallinity degree of graphite from graphite deposits hosted by migmatites and related rocks in northeast Minas Gerais indicates temperatures between 660 and $705^{\circ} \mathrm{C}$, whereas $P-T$ calculation using THERMOCALC yielded values of $790 \pm 40^{\circ} \mathrm{C}$ and $5.0 \pm 0.5 \mathrm{kbar}$ for metamorphic peak conditions; TWEEQU yielded $890 \pm 50^{\circ} \mathrm{C}$ and $6.7 \pm 0,6$ kbar (Belém, 2006).

\section{Location of the study area}

The investigated rocks are located in the south of Bahia, in the region of Teixeira de Freitas, Itanhém, Itamaraju and Jucuruçu (Fig. 2), and are part of the Jequitinhonha Complex, in accordance to the geological map of the area (Sampaio et al. 2004). Only outcrops where migmatites and granulites crop out were sampled.

\section{FIELD DESCRIPTION AND PETROGRAPHY OF GRANULITES AND MIGMATITES}

In the investigated region, diatexite, felsic and mafic granulites are the main rock types, and were intruded by charnockite and S-type cordierite-garnet granite bodies (Sampaio et al. 2004). Metamorphic rocks are part of the Jequitinhonha Complex, while intrusive bodies correspond

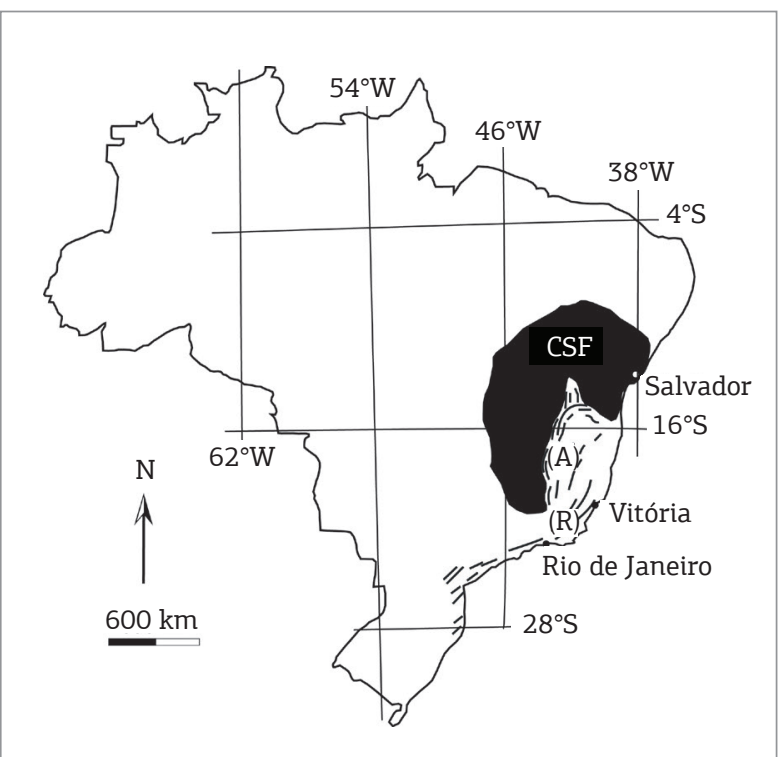

Figure 1. Map of Brazil with location of the Araçuaí (A) and Ribeira $(R)$ orogens and their positions in relation to the São Francisco Craton (CSF). The thin lines denote structural trend along the orogens whereas the craton area is marked in black (adapted from Alkmin et al. 2001).

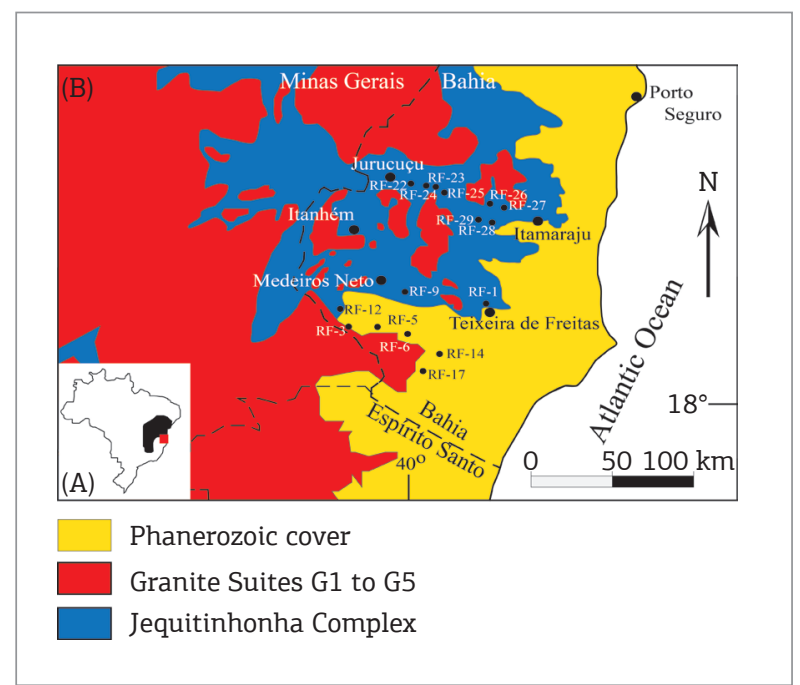

Figure 2. (A) Map of Brazil with location of the São Francisco Craton and the studied area. (B) Simplified geological map of the southern portion of Bahia and northeast Minas Gerais. Study samples are located and some of the samples seemingly from the Phanerozoic cover were collected in streams and rivers where Jequitinhonha Complex crops out, but cannot be represented in this scale (map adapted from Sampaio et al. 2004, and Cruz et al. 2012). 
to the G4 and G5 suites (Pedrosa-Soares et al. 2007), as mentioned above.

\section{Garnet-cordierite diatexite: leucosome and residue}

Using the classification of migmatites proposed by Sawyer (2008), the rock that dominates the investigated region is classified as garnet-cordierite diatexite, given that a high proportion of partial melting generated a rock dominated by neosome. Leucosome, melanosome and a mesocratic residue are recognized, formed of cordierite rich-domains with subordinate garnet that alternate with quartz-feldspar dominated domains. Cordierite and garnet may reach 30 to $40 \%$ in volume of some neosome. Due to high degree of partial melting and segregation of large volumes of melt, now represented by leucosome, no portion of the garnet-cordierite diatexite represents its original bulk-composition. The structures observed in the diatexite are stromatic (Fig. 3A), schlieren (Fig. 3B) and nebulitic (Fig. 3C). The leucosome veins may be either parallel to foliation, considered as formed in situ and present biotite selvedges at their edges (Fig. 3A), or cross-cut the foliation, as in source leucosome, bearing garnet porphyroblasts (Figs. 3D and 3E) or cordierite clusters (Fig. 3F). In most of the outcrops the rock is a mesocratic residue with homogeneous matrix, foliated or not, hosting up to $5-7 \mathrm{~cm}$ garnet porphyroblasts, and up to $40 \%$ of cordierite dispersed in the matrix. Garnet and cordierite may be associated with leucosome, which demonstrates a close relationship between the generation of peritectic porphyroblasts and biotite-related melt reactions (Figs. 3D to 3F). Leucosome blind veins are common and they merge with portions of trapped melt in the rock (Fig. 3D). Diatexite with nebulitic structure is common and is formed in low strain regions (Fig. 3G), where the volume of leucosome overcomes the residue, which also presents schlieren and schollen with no preferential orientation. Locally, the coalescence of leucosome veins can form smaller bodies of cordierite-garnet granite (Fig. $3 \mathrm{H}$ ).

All collected samples for thermobarometry are of the mesocratic residue with either none, or just small volumes of leucosome.

\section{In situ and in source leucosome petrography}

Observed in the petrographic microscope, leucosome veins may be divided into two compositional types. The first is dominated by quartz and cordierite, with subordinate amounts of feldspars, whereas garnet may be present or not; the second type has granitic composition, with similar proportions of quartz, K-feldspar and plagioclase, with minor cordierite and garnet. In quartz- and cordierite-dominated leucosome, quartz forms large elongated grains, sometimes more than $1 \mathrm{~cm}$ across; contacts are straight or jagged with other quartz grains and chess-board like sub-grains are present (Fig. 4A). The cordierite grains are elongated and rounded, with rare subhedral plagioclase inclusions (Fig 4B); they may contain inclusions of sillimanite, as fibrolite or larger xenoblastic grains, rounded biotite, monazite and zircon (Figs. 4C and 4D); edges commonly are replaced by a mixture of white mica, chlorite and carbonate. Feldspars occur because lenses are parallel to the foliation and at the edges of leucosome veins; grains are elongated in granoblastic texture, rarely subhedral (Fig. 4C). Subhedral plagioclase grains occur in the matrix, but it is not uncommon to recognize recrystallized rims, indicating crystallization from the entrapped melt, but with subsequent deformation (Fig. 4B). Garnet also occurs within the leucosome, forming grains with irregular edges and bearing rounded inclusions of quartz, biotite and rare plagioclase; these grains are interpreted as not totally dissolved during partial melting and enclosed by peritectic garnet. Melanosome is dominated by cordierite, rich in sillimanite inclusions; it occurs in leucosome edges and may be partially enveloped by coarse-grained biotite (Fig. 4D); in some domains garnet is added to the melanosome mineral assemblage and it is also partially replaced by biotite or biotite-quartz-feldspar symplectite; biotite occurs as large laths, at least $1 \mathrm{~mm}$ in size, close to garnet or cordierite, to very fine-grained away from them.

The second type of leucosome veins is dominated by K-feldspar (50\%), quartz (45\%) and plagioclase (5\%). $\mathrm{K}$-feldspar is mesoperthite, idiomorphic to subidiomorphic, with clear edges, without exsolutions. Plagioclase occurs in smaller amounts, and in some thin sections, is present only as myrmekite. Quartz occurs as interstitial phase between feldspar grains, indicating that it was the last phase to crystallize from the melt. It also occurs as rounded inclusions within feldspars. Cordierite and garnet may be present and have the same textural features as described above.

\section{Granite veins petrography}

Veins of garnet granite and garnet-cordierite granite are abundant, crosscut the diatexite and can also form small, metric, isolated bodies due to collected liquid from the leucosome network (Fig. 3H). An igneous serial texture is dominant, marked by the occurrence of phenocrysts of perthitic to mesoperthitic orthoclase, with rounded quartz inclusions; the largest grains have straight edges, though jagged contacts are not uncommon. Plagioclase is interstitial, comprising 5-8\% modal proportion, subordinate to quartz and orthoclase; grains present optical zoning and rounded quartz inclusions. Cordierite and garnet aggregates or porphyroblasts are common within the granite veins. 

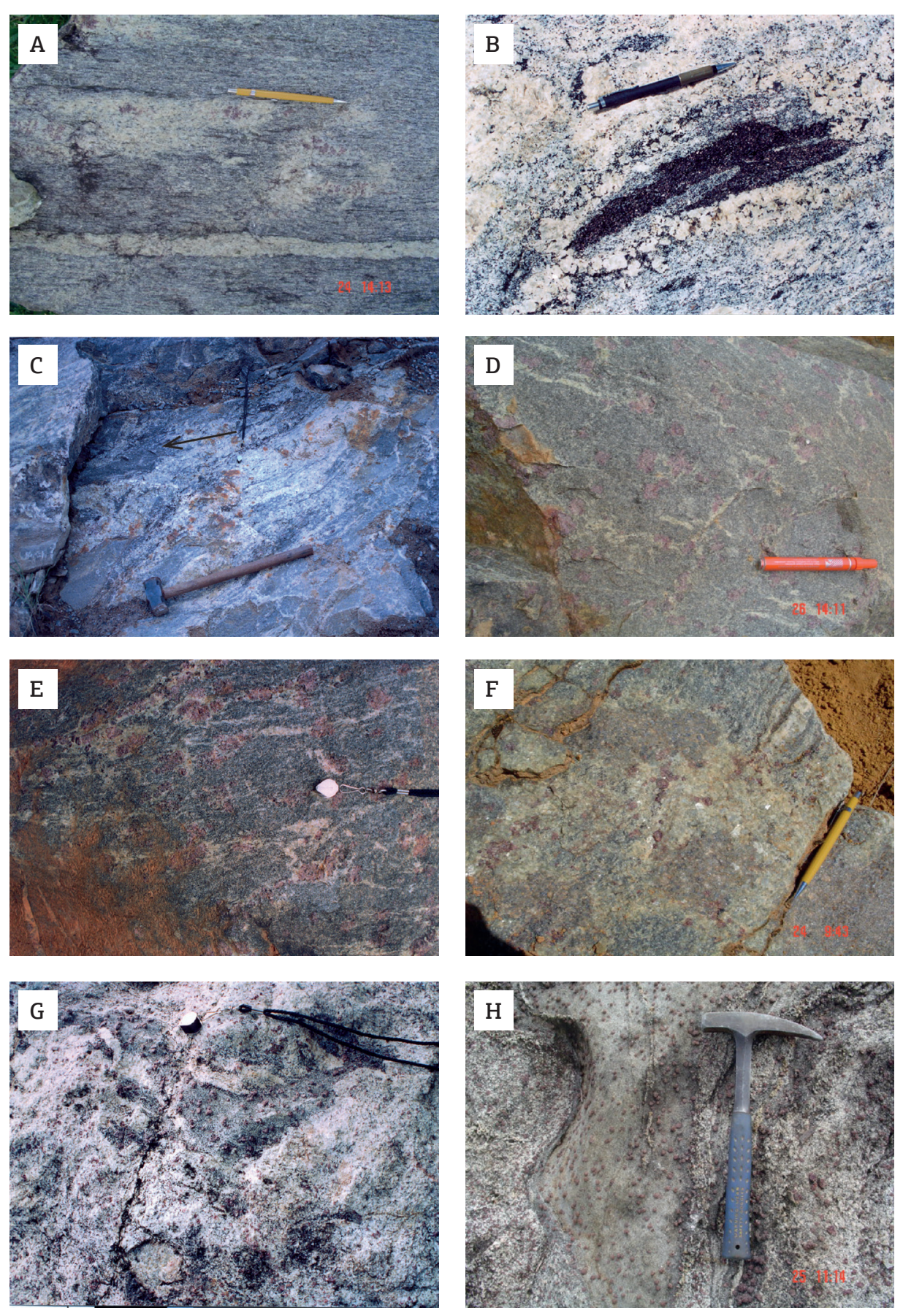

Figure 3. Field aspects of garnet-cordierite diatexite. (A) Garnet-cordierite diatexite with stromatic structure presents biotite selvedge at leucosome borders. Garnet porphyroblasts are clearly observed in the leucosome, especially within the upper one (RF-12). (B) Schlieren rich in biotite and garnet, inside coarse-grained quartzfeldspar leucosome, RF-12. (C) Garnet-cordierite diatexite with nebulitic structure, where leucosome veins are dispersed and wrap residue portions rich in cordierite and garnet (right side of the photo) and mafic rock scholen (indicated with an arrow), RF-03. (D) In situ leucosome veins forming a network within the garnet-cordierite diatexite. Up to $5 \mathrm{~cm}$ garnet porphyroblasts are observed inside diatexite and leucosome veins linking their origin to the partial melting reactions, RF-14. (E) Leucosome veins are disposed parallel to main foliation and bear garnet porphyroblasts of 3 to $7 \mathrm{~cm}$, which also may be inside the residue (grey portion), RF-20. (F) Cordierite clusters within garnet-rich leucosome that also crosscuts the residue main foliation, RF-09. (G) Nebulitic diatexite with plenty garnet porphyroblasts; several scholen of paleosome are disconnected, but still preserve some metamorphic foliation, RF-13. (H) Garnet granite vein formed due to extraction and coalescence of leucosome veins from adjacent diatexite, RF-13. 
Garnet contains biotite and rounded quartz inclusions, whereas cordierite occurs as isolated grains or as clusters of xenoblastic grains with inclusions of biotite or sillimanite, which may, in some cases, be as abundant as the host cordierite. Locally, late deformation imprints a protomylonite texture on some veins, generating strong orientation, wavy extinction, sub-grains, new grains, and deformation bands, in both quartz and feldspars.

\section{Residue petrography}

The residue portion of the garnet-cordierite diatexite makes up between 30 to $70 \%$ of its volume. It is a mesocratic rock with gneissic aspect. The residue is dominated by cordierite (20 to $45 \%$ ), quartz (20 to $35 \%$ ) and orthoclase (10 to $30 \%$ ), with varied proportions of garnet (1 to $30 \%$ ) and plagioclase (1 to $15 \%$ ); biotite is mostly retrometamorphic and in smaller amounts $(<8 \%)$. Monazite, zircon, apatite and Fe-Ti oxide are the most common accessory phases, along with sillimanite and green spinel. The rock texture is granoblastic but oriented, with medium- to coarse-grained grain size, larger than $5 \mathrm{~mm}$ in average (Fig. 5A). Lenticular clusters of feldspar and cordierite, elongated and recrystallized quartz, as well as biotite define the foliation. The cordierite grains may be clear, but it is common to have rounded or xenoblastic inclusions of sillimanite, biotite, and green spinel, with minor amounts of monazite and zircon (Fig. 5B).
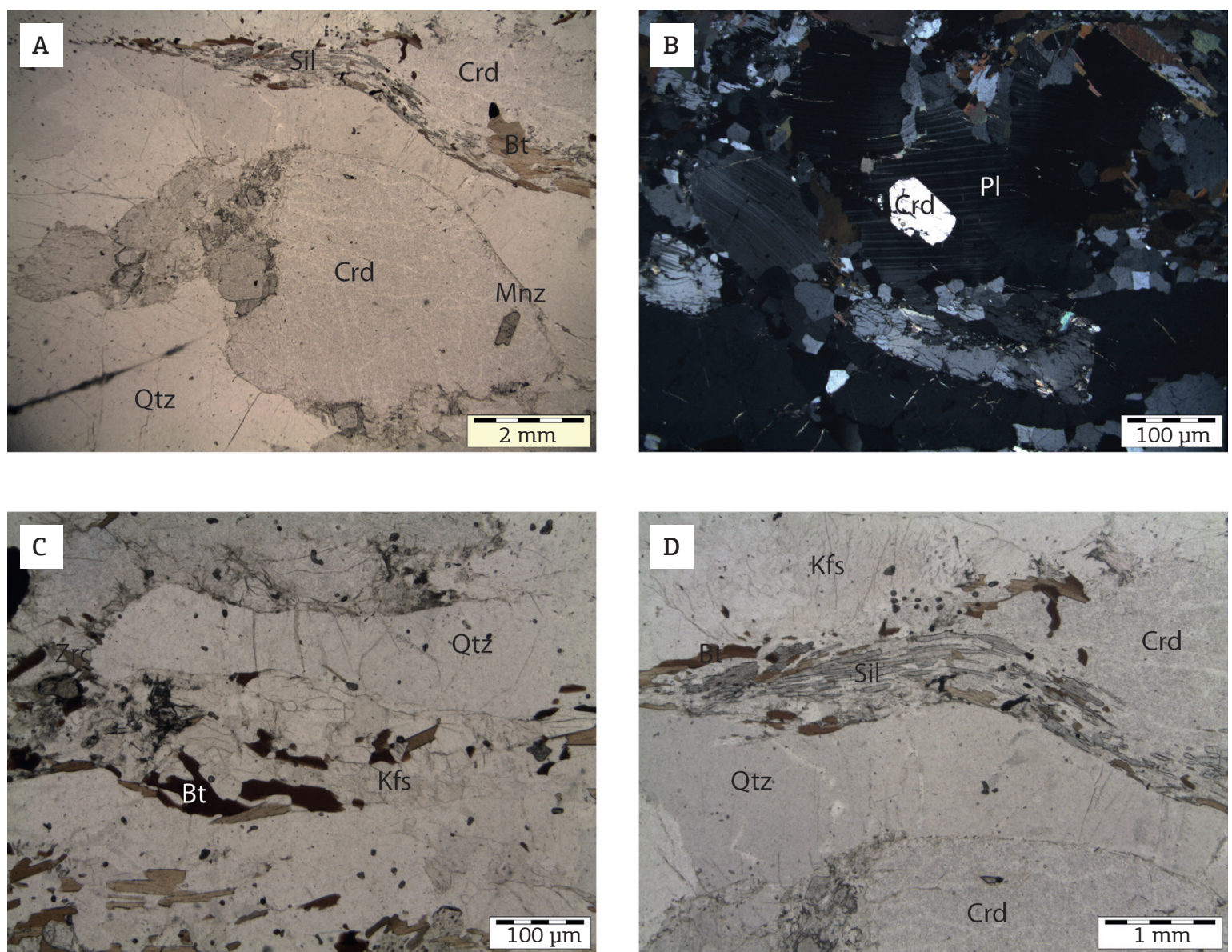

Figure 4. Leucosome related microstructures. (A) Leucosome dominated by cordierite and quartz. In the field of view, cordierite porphyroblast with pinitized rims, large inclusion of monazite and melanosome formed mainly of cordierite, partially replaced by late sillimanite and biotite. RF-01, plane-polarized light. (B) Sub-idioblastic grain of cordierite inside a subhedral plagioclase crystal, which presents partially recrystallized borders, within leucosome. RF-01, cross-polarized light. (C) Orthoclase and quartz lenses defining orientation in leucosome, accompanied by biotite crystals. RF-01, plane-polarized light. (D) Detail of Fig. 4A. Cordierite in melanosome is partially replaced by retrometamorphic selvedge of sillimanite and biotite. RF-01, plane-polarized light (abbreviations are after Kretz 1983). 
Garnet is poikiloblastic, with xenoblastic or rounded inclusions of quartz, plagioclase and cordierite, itself with inclusions of sillimanite, biotite, and zircon (Figs. 5C and 5D). Garnet and cordierite, within the leucosome, may have corroded and irregular edges; some rims are replaced by biotite, usually in symplectites with quartz and feldspars; sometimes magnetite and, very rarely, sillimanite is present (Fig. 5D). It is not uncommon to observe an irregular cordierite corona around garnet, both partially replaced by biotite-quartz-feldspar symplectite, which in turn is surrounded by thin graphic intergrowth of quartz and feldspar (Figs. 5E and 5F). This texture represents consecutive reactions between entrapped melt and $\mathrm{Fe}-\mathrm{Mg}$ porphyroblasts and final crystallization of the melt phase. The residue is poor in plagioclase, which occurs as rare subhedral (Fig. 5G) or interstitial grains, sometimes as films in optical continuity (Fig. $5 \mathrm{H}$ ), which were formed due to crystallization of entrapped melt.

\section{Felsic granulite - field aspects and petrography}

The felsic granulite is subordinated to the garnet-cordierite diatexite. The contact relationship between them cannot always be defined, but in some outcrops a transition is observed between biotite-rich diatexite and felsic granulite, and the contact is parallel to the regional foliation (Fig. 6A). Leucosome veins are arranged parallel to the regional foliation (Fig. 6B), with blind endings and, locally, cross cutting felsic granulite foliation. Inside leucosome, orthopyroxene and garnet porphyroblasts are commonly observed.

Felsic granulite is composed of quartz, plagioclase, orthoclase, orthopyroxene, garnet, biotite and ilmenite; apatite and zircon are the main accessory phases. The texture is granoblastic and oriented due to the disposition of elongated orthopyroxene, feldspars and ilmenite grains. Quartz forms elongated aggregates of large grains, parallel to the foliation, in flaser texture. Among the feldspars, plagioclase stands out, and orthoclase is mesoperthitic. Orthopyroxene and garnet occur as porphyroblasts, 2 to $3 \mathrm{~mm}$ long (Fig. 7A), though the latter may reach diameter larger than $1 \mathrm{~cm}$. Garnet is xenoblastic, presents many quartz and plagioclase inclusions and the edges are partially replaced by biotite (Fig. 7B), which also occurs at orthopyroxene rims (Fig. 7A). Quartz and feldspars films mimicking the entrapped melt are rare, but occur in triple junctions (Fig. 7C) or around subhedral biotite and among plagioclase grains (Fig. 7D).

\section{MINERAL CHEMISTRY}

Based on petrography, five thin sections were selected for analysis using an Electron Probe Microanalyzer, by
Cameca, model SX 100, with four spectrometers equipped with two TAP crystals, one LIF and one PET. The analyzes were performed with conditions of $15 \mathrm{kV}, 15 \mathrm{nA}$ and beam of $5 \mu$ diameter at the Laboratoire Magmas et Volcans, at the Département des Sciences de la Terre, Université Blaise Pascal, Clermont-Ferrand, France. The following chemical elements were analyzed for each of the listed minerals:

garnet - $\mathrm{Si}, \mathrm{Ti}, \mathrm{Al}, \mathrm{Cr}, \mathrm{Fe}, \mathrm{Mn}, \mathrm{Mg}$ and $\mathrm{Ca}$;

cordierite $-\mathrm{Si}, \mathrm{Ti}, \mathrm{Al}, \mathrm{Cr}, \mathrm{Fe}, \mathrm{Mn}, \mathrm{Mg}, \mathrm{Na}$ and $\mathrm{K}$;

- feldspars - Si, Al, Fe, Mn, Ca, $\mathrm{Na}$ and $\mathrm{K}$;

orthopyroxene $-\mathrm{Si}, \mathrm{Ti}, \mathrm{Al}, \mathrm{Cr}, \mathrm{Fe}, \mathrm{Mn}, \mathrm{Mg}$ and $\mathrm{Ca}$;

biotite - Si, Ti, Al, Cr, Fe, Mn, Mg, Ca, Na, K and F;

spinel-Si, Ti, Al, Cr, Zn, Fe, Mn, and Mg.

Punctual analyses were performed on feldspar, biotite and cordierite, core and rim, in at least three grains in two or three different fields of the same thin section. In garnet and orthopyroxene, the composition profiles were built with eight to twenty points across the porphyroblasts. The minerals of five samples were analyzed, three samples of garnet-cordierite diatexite residue (RF-01, RF-06, RF-24) and also two of felsic granulite (RF-03 and RF-16). From the garnet-cordierite diatexite, cordierite, garnet, feldspar, biotite and spinel were analyzed; and from felsic granulite, orthopyroxene, garnet, feldspar and biotite were analyzed. Representative analyses of mineral chemical compositions are presented in Tables 1 and 2 .

\section{Garnet}

Garnet chemistry is controlled by bulk rock composition and, in each sample, specific features are recognized. In the garnet-cordierite diatexite, garnet composition is dominated by end-members almandine and pyrope, with values between 70 and $80 \%$ and between 15 and 30\% respectively, depending on the sample (Fig. 8). In the three samples, the almandine molecule increases subtly from core to rim, while pyrope decreases. The amounts of calcium and manganese are low, with concentrations between 2 and 3\%, and grossular features flat profile and spessartine increases slightly toward the edges. The composition may be generally described as alm ${ }_{70}$ pyr $_{25}$ grs $_{3} \mathrm{sps}_{2}$.

In felsic granulite, garnet composition is also dominated by the almandine molecule, followed by pyrope, grossular and spessartine, presenting, however, differences in relation to garnet of garnet-cordierite diatexite. In the felsic granulite, garnet composition is richer in calcium than in diatexite, reflected in the increased amount of grossular, around $10 \%$, and corroborated by the common presence of plagioclase. The compositional profiles are almost flat, with small variations derived from slight increase of iron and decreasing magnesium towards the rims. Garnet composition 

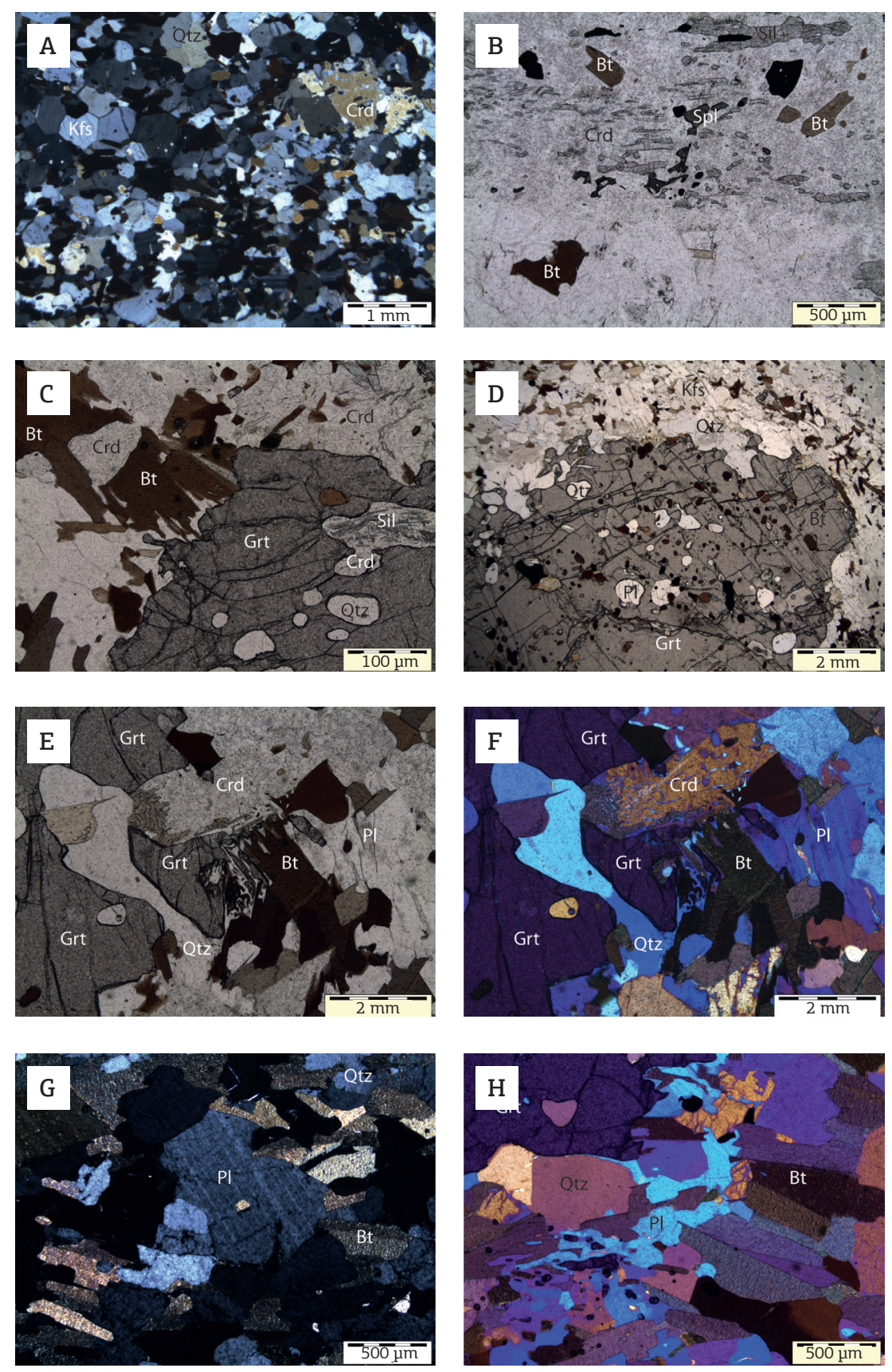

Figure 5. Microstructures related to residue of garnet-cordierite diatexite. (A) Residue matrix of garnet-cordierite diatexite with oriented granoblastic texture, defined by grains of quartz, orthoclase and cordierite. RF-6A, crosspolarized light. (B) Core of cordierite porphyroblast (upper cloudy portion of photomicrograph), with xenoblastic inclusions of sillimanite, spinel, Ti-Fe oxides and biotite. RF-9B, plane-polarized light. (C) Garnet corroded rim in contact with cordierite, both partially replaced by biotite-feldspar-quartz symplectite. Biotite is larger when in contact with cordierite (central and upper left portion). Most rounded inclusions inside garnet are quartz with one of cordierite with fibrolite. RF-01, plane-polarized light. (D) Garnet porphyroblast, peritectic phase with several either rounded or xenoblastic inclusions of grains partially dissolved during melting reactions, mainly quartz, plagioclase and biotite. RF-6A, plane-polarized light. (E) Detail of garnet porphyroblast rim, partially replaced by biotite-feldspar-quartz symplectite when in contact with cordierite. RF-29A, plane-polarized light. (F) Same as before, but photomicrograph was taken with crossed-polarized light plus gypsum plate to enhance the optical continuity of quartz in the matrix and the one in the symplectite RF-29A. (G) Subhedral crystal of plagioclase in residue crystallized from trapped melt. RF-01, crossed-polarized light. (H) Interstitial plagioclase among quartz, biotite and garnet, crystallized from and mimicking entrapped melt inside residue, as evidenced by its complete anhedral form, with cuspate terminations and optical continuity along the field of view. RF-01, crossed-polarized light plus gypsum plate. 

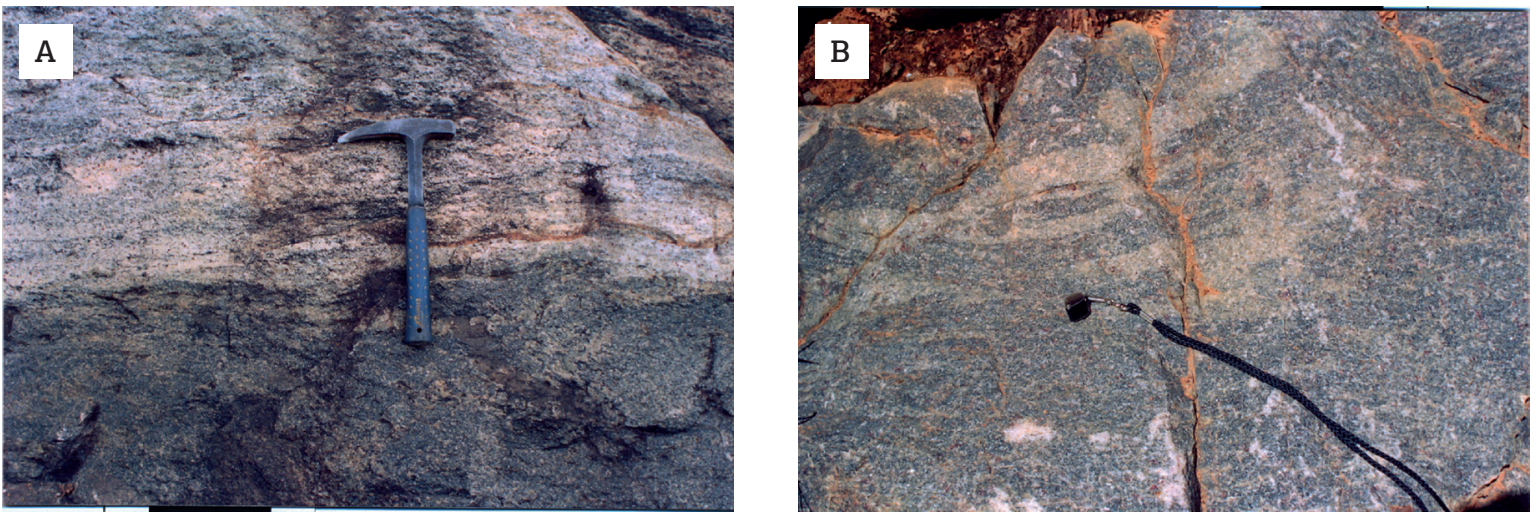

Figure 6. Field aspects of felsic granulite. (A) Contact between biotite diatexite (upper portion) and felsic granulite (bottom), that can be either transitional or abrupt, RF-03. (B) Felsic granulite with in situ and in source leucosome veins, as some leucosome crosscuts the main foliation, RF-06.
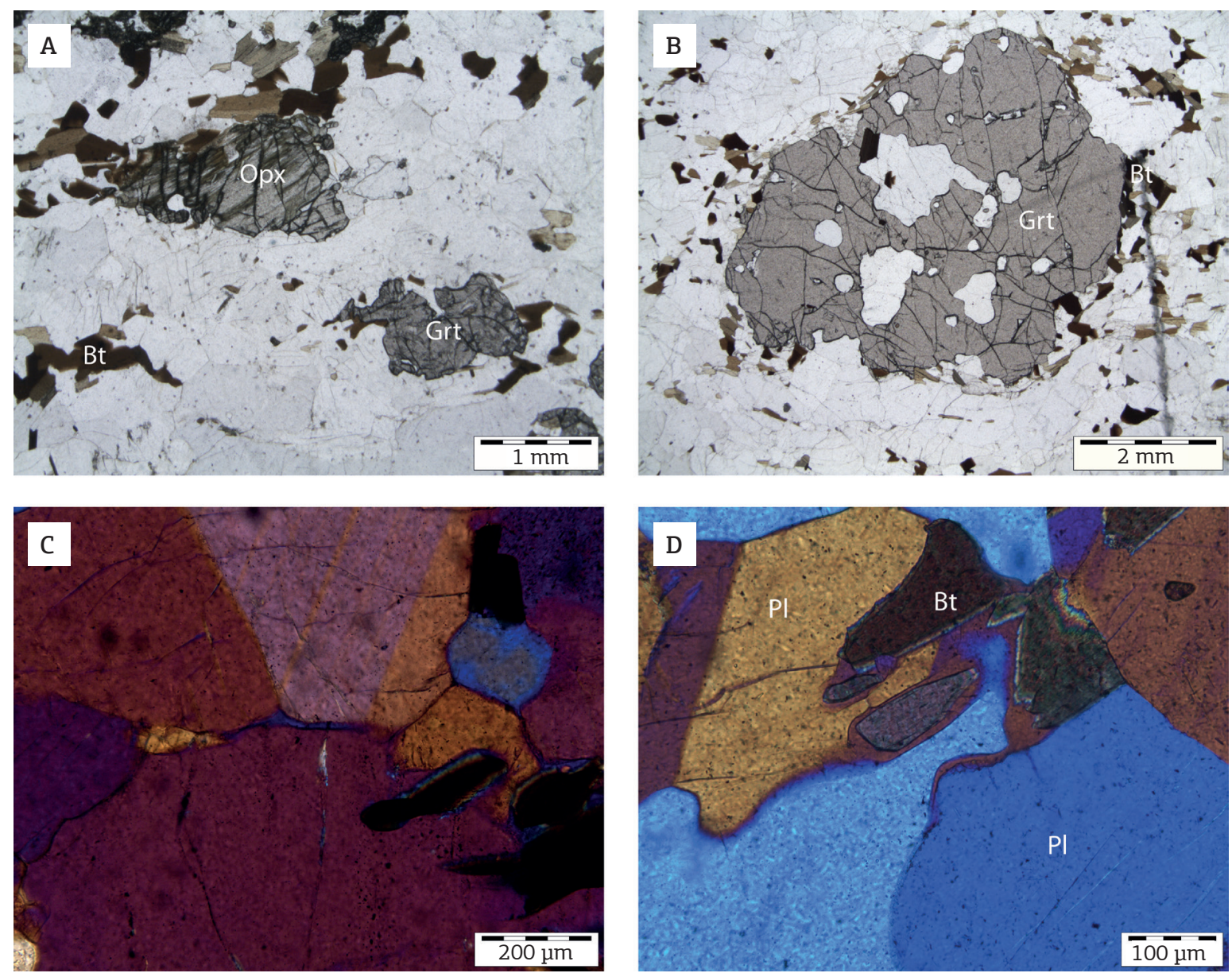

Figure 7. Microstructures related felsic granulite - sample RF-3A. (A) Orthopyroxene and garnet porphyroblasts in matrix constituted of quartz, orthoclase and plagioclase. Late biotite partially replaced both mafic minerals. Plane-polarized light. (B) Garnet porphyroblast with either rounded or amoeba-like inclusions of quartz and feldspars, interpreted as grains partially dissolved by melting and included in peritectic garnet. Late biotite occurs at garnet rim. Plane-polarized light. (C) Rare interstitial quartz filling a triple junction of three feldspar grains, mimicking an entrapped melt phase. It is a rare microstructure because felsic granulite is a restite rock. Crossed-polarized light plus gypsum plate. (D) Quartz film surrounding biotite and along contacts of plagioclase grains. It presents optical continuity and cuspate terminations and is interpreted as crystallization product of trapped melt. Crossed-polarized light plus gypsum plate. 
Table 1. Selected microprobe analyses of minerals from garnet-cordierite diatexite.

\begin{tabular}{|c|c|c|c|c|c|c|c|c|c|c|c|c|c|c|c|c|c|}
\hline \multirow{2}{*}{$\begin{array}{l}\text { Sample } \\
\text { Mineral }\end{array}$} & \multicolumn{6}{|c|}{ RF-1 } & \multicolumn{5}{|c|}{ RF-6 } & \multicolumn{6}{|c|}{ RF-24 } \\
\hline & Grt & Grt & Kfs & Pl & Crd & Bt & Grt & Grt & Kfs & Crd & Bt & Grt & Grt & Kfs & Pl & Crd & Bt \\
\hline Postion & core & rim & & core & & & core & rim & core & core & core & core & rim & & & & \\
\hline $\mathrm{SiO}_{2}$ & 37.68 & 37.45 & 64.78 & 61.17 & 48.79 & 35.76 & 37.77 & 38.13 & 64.18 & 48.56 & 36.35 & 38.02 & 36.91 & 64.75 & 61.70 & 48.37 & 36.17 \\
\hline $\mathrm{TiO}_{2}$ & 0.01 & 0.00 & & & 0.00 & 4.06 & 0.00 & 0.03 & & 0.02 & 4.71 & 0.05 & 0.03 & & & 0.01 & 4.66 \\
\hline $\mathrm{Al}_{2} \mathrm{O}_{3}$ & 21.59 & 21.26 & 18.69 & 23.76 & 33.02 & 16.70 & 21.71 & 21.66 & 18.97 & 32.70 & 16.51 & 21.74 & 21.06 & 18.43 & 23.69 & 32.99 & 16.66 \\
\hline $\mathrm{Cr}_{2} \mathrm{O}_{3}$ & 0.00 & 0.16 & & & 0.00 & 0.03 & 0.00 & 0.07 & & 0.01 & 0.11 & 0.00 & 0.04 & & & 0.00 & 0.21 \\
\hline $\mathrm{Fe}_{2} \mathrm{O}_{3}$ & 1.28 & 1.49 & 0.00 & 0.01 & 0.29 & & 1.43 & 0.83 & 0.00 & 1.30 & & 1.37 & 1.85 & 0.00 & 0.10 & 1.33 & \\
\hline $\mathrm{FeO}$ & 32.53 & 34.15 & & & 6.94 & 19.32 & 30.48 & 31.84 & & 6.81 & 17.56 & 31.04 & 34.36 & & & 6.84 & 17.81 \\
\hline $\mathrm{MnO}$ & 1.02 & 1.29 & 0.02 & 0.00 & 0.06 & 0.10 & 0.94 & 1.07 & 0.06 & 0.11 & 0.07 & 0.88 & 1.43 & 0.01 & 0.01 & 0.06 & 0.01 \\
\hline $\mathrm{MgO}$ & 5.95 & 4.67 & & & 8.96 & 10.23 & 7.11 & 6.53 & & 8.73 & 11.01 & 7.00 & 4.01 & & & 8.74 & 11.02 \\
\hline $\mathrm{CaO}$ & 0.71 & 0.79 & 0.11 & 5.29 & 0.00 & 0.00 & 0.83 & 0.84 & 0.12 & 0.00 & 0.00 & 0.85 & 0.94 & 0.06 & 5.22 & 0.00 & 0.05 \\
\hline $\mathrm{Na}_{2} \mathrm{O}$ & & & 2.51 & 8.99 & 0.07 & 0.11 & & & 1.67 & 0.13 & 0.09 & & & 2.69 & 8.85 & 0.08 & 0.14 \\
\hline $\mathrm{K}_{2} \mathrm{O}$ & & & 13.46 & 0.27 & 0.01 & 10.00 & & & 14.83 & 0.02 & 9.34 & & & 13.33 & 0.13 & 0.01 & 9.32 \\
\hline Total & 100.75 & 101.26 & 99.58 & 99.49 & 98.16 & 96.31 & 100.26 & 100.99 & 99.84 & 98.39 & 95.76 & 100.95 & 100.61 & 99.28 & 99.69 & 98.44 & 96.06 \\
\hline Oxygen & 12.000 & 12.000 & 8.000 & 8.000 & 18.000 & 11.000 & 12.000 & 12.000 & 8.000 & 18.000 & 11.000 & 12.000 & 12.000 & 8.000 & 8.000 & 18.000 & 11.000 \\
\hline $\mathrm{Si}$ & 2.961 & 2.960 & 2.982 & 2.735 & 5.001 & 2.710 & 2.956 & 2.976 & 2.965 & 4.984 & 2.733 & 2.959 & 2.950 & 2.989 & 2.747 & 4.961 & 2.715 \\
\hline $\mathrm{Ti}$ & 0.000 & 0.000 & & & 0.000 & 0.231 & 0.000 & 0.002 & & 0.002 & 0.267 & 0.003 & 0.002 & & & 0.001 & 0.263 \\
\hline $\mathrm{Al}$ & 2.001 & 1.981 & 1.014 & 1.253 & 3.991 & 1.492 & 2.003 & 1.992 & 1.033 & 3.956 & 1.463 & 1.995 & 1.984 & 1.003 & 1.244 & 3.990 & 1.474 \\
\hline $\mathrm{Cr}$ & 0.000 & 0.010 & & & 0.000 & 0.002 & 0.000 & 0.004 & & 0.001 & 0.007 & 0.000 & 0.003 & & & 0.000 & 0.012 \\
\hline $\mathrm{Fe}^{3+}$ & 0.076 & 0.089 & 0.000 & 0.000 & 0.022 & & 0.084 & 0.049 & 0.000 & 0.101 & 1.104 & 0.080 & 0.111 & 0.000 & 0.003 & 0.103 & \\
\hline $\mathrm{Fe}^{2+}$ & 2.138 & 2.257 & & & 0.595 & 1.224 & 1.995 & 2.078 & & 0.584 & 0.004 & 2.021 & 2.296 & & & 0.586 & 1.118 \\
\hline $\mathrm{Mn}$ & 0.068 & 0.086 & 0.001 & 0.000 & 0.005 & 0.006 & 0.063 & 0.071 & 0.002 & 0.009 & 1.233 & 0.058 & 0.097 & 0.000 & 0.000 & 0.005 & 0.001 \\
\hline $\mathrm{Mg}$ & 0.697 & 0.550 & & & 1.368 & 1.155 & 0.829 & 0.759 & & 1.335 & 0.000 & 0.813 & 0.478 & & & 1.337 & 1.233 \\
\hline $\mathrm{Ca}$ & 0.060 & 0.067 & 0.006 & 0.253 & 0.000 & 0.000 & 0.070 & 0.070 & 0.006 & 0.000 & 0.014 & 0.071 & 0.080 & 0.003 & 0.249 & 0.000 & 0.004 \\
\hline $\mathrm{Na}$ & & & 0.224 & 0.779 & 0.015 & 0.016 & & & 0.150 & 0.026 & 0.896 & & & 0.241 & 0.764 & 0.016 & 0.021 \\
\hline K & & & 0.791 & 0.015 & 0.002 & 0.967 & & & 0.875 & 0.002 & & & & 0.786 & 0.007 & 0.001 & 0.894 \\
\hline cations & 8.000 & 8.000 & 5.019 & 5.036 & 11.000 & 7.804 & 8.000 & 8.000 & 5.031 & 11.000 & 7.721 & 8.000 & 8.000 & 5.022 & 5.015 & 11.000 & 7.736 \\
\hline alm & 72.16 & 76.25 & & & & & 67.47 & 69.78 & & & & 68.21 & 77.80 & & & & \\
\hline pyr & 23.52 & 18.58 & & & & & 28.04 & 25.49 & & & & 27.44 & 16.20 & & & & \\
\hline sps & 2.29 & 2.91 & & & & & 2.13 & 2.38 & & & & 1.96 & 3.29 & & & & \\
\hline gros & 2.02 & 2.26 & & & & & 2.37 & 2.35 & & & & 2.40 & 2.71 & & & & \\
\hline$a b$ & & & 21.94 & 74.40 & & & & & 14.55 & & & & & 23.40 & 74.90 & & \\
\hline an & & & 0.59 & 24.16 & & & & & 0.58 & & & & & 0.29 & 24.41 & & \\
\hline or & & & 77.47 & 1.43 & & & & & 84.87 & & & & & 76.31 & 0.69 & & \\
\hline$X_{\mathrm{Mg}}$ & & & & & 0.70 & 0.49 & & & & 0.70 & 0.53 & & & & & 0.70 & 0.52 \\
\hline
\end{tabular}

Grt: garnet; Crd: cordierite; Kfs: K-feldspar; Pl: plagioclase; Bt: biotite. 
Table 2. Selected microprobe analyses of minerals from felsic granulite.

\begin{tabular}{|c|c|c|c|c|c|c|c|c|c|c|c|c|c|c|}
\hline \multirow{2}{*}{$\begin{array}{l}\text { Sample } \\
\text { Mineral }\end{array}$} & \multicolumn{7}{|c|}{ RF-16 } & \multicolumn{7}{|c|}{ RF-3 } \\
\hline & Grt & Grt & Kfs & Pl & Opx & Opx & Bt & Grt & Grt & Kfs & Pl & Opx & Opx & Bt \\
\hline Position & core & rim & & core & core & rim & & core & rim & & & core & rim & \\
\hline $\mathrm{SiO}_{2}$ & 37.50 & 37.39 & 64.42 & 54.42 & 50.57 & 50.62 & 36.24 & 37.77 & 37.48 & 64.47 & 58.46 & 48.79 & 49.80 & 35.52 \\
\hline $\mathrm{TiO}_{2}$ & 0.02 & 0.01 & & & 0.07 & 0.08 & 5.93 & 0.03 & 0.02 & & & 0.06 & 0.08 & 4.97 \\
\hline $\mathrm{Al}_{2} \mathrm{O}_{3}$ & 21.26 & 21.34 & 18.38 & 28.13 & 1.53 & 1.22 & 14.30 & 21.40 & 21.39 & 18.37 & 26.55 & 1.25 & 1.10 & 15.27 \\
\hline $\mathrm{Cr}_{2} \mathrm{O}_{3}$ & 0.00 & 0.06 & & & 0.00 & 0.00 & 0.04 & 0.00 & 0.00 & & & 0.00 & 0.05 & 0.00 \\
\hline $\mathrm{Fe}_{2} \mathrm{O}_{3}$ & 1.60 & 2.01 & 0.00 & 0.36 & 0.11 & 0.57 & & 1.34 & 1.62 & 0.08 & 0.16 & 1.49 & 0.31 & \\
\hline $\mathrm{FeO}$ & 29.52 & 29.13 & & & 30.48 & 29.83 & 19.54 & 31.33 & 30.75 & & & 33.17 & 34.69 & 21.32 \\
\hline $\mathrm{MnO}$ & 1.46 & 1.49 & 0.00 & 0.04 & 0.44 & 0.47 & 0.11 & 1.68 & 1.58 & 0.00 & 0.03 & 0.69 & 0.60 & 0.06 \\
\hline $\mathrm{MgO}$ & 5.50 & 5.51 & & & 16.38 & 16.86 & 10.68 & 4.57 & 4.62 & & & 13.59 & 13.43 & 9.50 \\
\hline $\mathrm{CaO}$ & 3.17 & 3.33 & 0.04 & 11.22 & 0.33 & 0.21 & 0.03 & 3.13 & 3.32 & 0.08 & 8.66 & 0.25 & 0.31 & 0.07 \\
\hline $\mathrm{Na}_{2} \mathrm{O}$ & & & 0.40 & 5.14 & & & 0.00 & & & 0.59 & 6.47 & & & 0.03 \\
\hline $\mathrm{K}_{2} \mathrm{O}$ & & & 16.25 & 0.31 & & & 9.74 & & & 16.10 & 0.47 & & & 9.88 \\
\hline Total & 100.03 & 100.27 & 99.51 & 99.62 & 99.92 & 99.85 & 96.61 & 101.24 & 100.78 & 99.70 & 100.80 & 99.30 & 100.37 & 96.63 \\
\hline Oxygens & 12.000 & 12.000 & 8.000 & 8.000 & 6.000 & 6.000 & 11.000 & 12.000 & 12.000 & 8.000 & 8.000 & 6.000 & 6.000 & 11.000 \\
\hline $\mathrm{Si}$ & 2.961 & 2.947 & 2.994 & 2.470 & 1.961 & 1.962 & 2.743 & 2.968 & 2.956 & 2.991 & 2.599 & 1.946 & 1.967 & 2.714 \\
\hline $\mathrm{Ti}$ & 0.001 & 0.000 & & & 0.002 & 0.002 & 0.338 & 0.001 & 0.001 & & & 0.002 & 0.002 & 0.285 \\
\hline $\mathrm{Al}$ & 1.980 & 1.983 & 1.007 & 1.505 & 0.070 & 0.056 & 1.276 & 1.983 & 1.989 & 1.005 & 1.391 & 0.059 & 0.051 & 1.375 \\
\hline $\mathrm{Cr}$ & 0.000 & 0.004 & & & 0.000 & 0.000 & 0.002 & 0.000 & 0.000 & & & 0.000 & 0.001 & 0.000 \\
\hline $\mathrm{Fe}^{3+}$ & 0.095 & 0.119 & 0.000 & 0.012 & 0.003 & 0.017 & & 0.079 & 0.096 & 0.003 & 0.005 & 0.045 & 0.009 & \\
\hline $\mathrm{Fe}^{2+}$ & 1.950 & 1.920 & & & 0.988 & 0.966 & 1.237 & 2.059 & 2.028 & & & 1.106 & 1.146 & 1.362 \\
\hline $\mathrm{Mn}$ & 0.097 & 0.100 & 0.000 & 0.001 & 0.015 & 0.015 & 0.007 & 0.112 & 0.106 & 0.000 & 0.001 & 0.023 & 0.020 & 0.004 \\
\hline $\mathrm{Mg}$ & 0.647 & 0.647 & & & 0.947 & 0.973 & 1.204 & 0.535 & 0.543 & & & 0.808 & 0.790 & 1.082 \\
\hline $\mathrm{Ca}$ & 0.268 & 0.281 & 0.002 & 0.546 & 0.014 & 0.009 & 0.002 & 0.264 & 0.281 & 0.004 & 0.413 & 0.011 & 0.013 & 0.006 \\
\hline $\mathrm{Na}$ & & & 0.036 & 0.453 & & & 0.000 & & & 0.053 & 0.558 & & & 0.005 \\
\hline $\mathrm{K}$ & & & 0.964 & 0.018 & & & 0.942 & & & 0.954 & 0.027 & & & 0.964 \\
\hline cations & 8.000 & 8.000 & 5.003 & 5.006 & 4.000 & 4.000 & 7.751 & 8.000 & 8.000 & 5.009 & 4.994 & 4.000 & 4.000 & 7.797 \\
\hline alm & 65.83 & 65.13 & & & & & & 69.33 & 68.56 & & & & & \\
\hline pyr & 21.84 & 21.95 & & & & & & 18.01 & 18.36 & & & & & \\
\hline sps & 3.27 & 3.39 & & & & & & 3.77 & 3.58 & & & & & \\
\hline gros & 9.05 & 9.53 & & & & & & 8.89 & 9.50 & & & & & \\
\hline$a b$ & & & 3.59 & 44.54 & & & & & & 5.24 & 55.91 & & & \\
\hline an & & & 0.20 & 53.69 & & & & & & 0.40 & 41.38 & & & \\
\hline or & & & 96.21 & 1.77 & & & & & & 94.36 & 2.71 & & & \\
\hline$X_{\mathrm{Mg}}$ & & & & & 0.489 & 0.502 & 0.49 & & & & & 0.422 & 0.408 & 0.44 \\
\hline
\end{tabular}

Grt: garnet; Kfs: K-feldspar; Opx: orthopyroxene; Pl: plagioclase; Bt: biotite. 
is also controlled by variations in granulite bulk composition, as RF-03 is richer in iron and poorer in magnesium, with average composition $\mathrm{alm}_{70} \mathrm{pyr}_{20} \mathrm{grs}_{8} \mathrm{sps}_{2}$, and RF-16 is richer in magnesium with average composition alm ${ }_{65} \mathrm{pyr}-$ ${ }_{25}$ grs $_{10} \mathrm{sps}_{5}$ (Fig. 9).

\section{Cordierite}

Cordierite occurs exclusively in the garnet-cordierite diatexite and presents homogeneous composition in all analyzed samples, with average $X_{\mathrm{Mg}} 0.69, \mathrm{Fe} 0.62$ apfu, and without chemical zoning.

\section{Feldspars}

In the garnet-cordierite diatexite, feldspars have no compositional zoning; orthoclase may contain between 16 and $22 \%$ of albite molecule with pure albite exsolution lamellae. The composition of K-feldspar was not reintegrated. The plagioclase composition is $\mathrm{An}_{24}$.

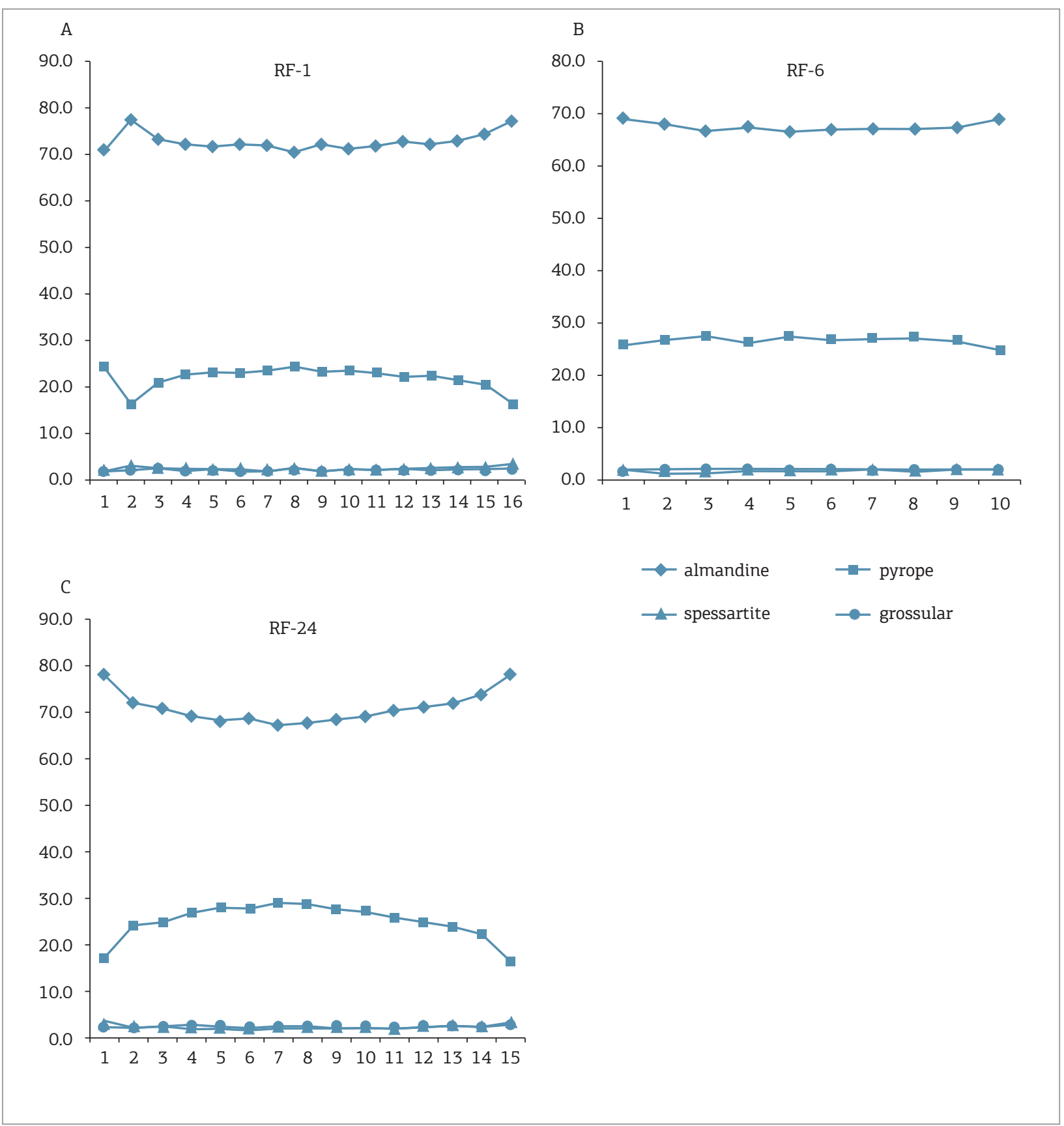

Figure 8. Garnet composition along traverses in selected grains of garnet-cordierite diatexite. (A) RF-01, (B) RF-06, (C) RF-24. 
Orthoclase is almost pure in felsic granulite, with a maximum of $A b_{5}$, while the plagioclase composition is $A n_{47}$ in sample RF-16, richer in magnesium, and $\mathrm{An}_{40}$ in sample RF-03, poorer in magnesium.

\section{Orthopyroxene}

Orthopyroxene is present only in felsic granulite and its composition varies according to the amount of magnesium in the bulk rock composition. In RF-16, richer in magnesium, $X_{\mathrm{Mg}}$ is 0.48 , the grains have mild chemical zoning, with aluminum richer core, $0.07 \mathrm{apfu}$, with rims with $0.056 \mathrm{apfu}$, which is offset by the increase in magnesium, $X_{\mathrm{Mg}}=0.50$. In sample RF-03, poorer in magnesium, the analyzed grains present no chemical zoning, with $X_{\mathrm{Mg}}$ between 0.41 and 0.42 , and aluminum between 0.052 and 0.055 apfu.

\section{Biotite}

Biotite occurs in three textural types in the garnet-cordierite diatexite, either as porphyroblasts, grain clusters or with quartz and feldspar symplectite. The composition is homogeneous with $X_{\mathrm{Mg}}$ around 0.54 in the first two types, but in symplectite $X_{\mathrm{Mg}}$ is lower, 0.50 . The Ti content is high, with values up to $5.2 \%$ (0.37 apfu) in porphyroblasts and $4.5 \%$ (0.26 apfu) in symplectite.

\section{CALCULATION OF PRESSURE AND TEMPERATURE OF METAMORPHISM AND PARTIAL MELTING}

The calculation of $P-T$ metamorphic peak conditions for described granulites and diatexites is presented in Tables 3 and 4, with a series of results, the metamorphic and partial melting meaning of which, as well as their tectonic implications, will be discussed below.

The first $P-T$ calculations are made with the software THERMOCALC (Powell \& Holland 1988), in which temperature and pressure are calculated separately, then the two variables are calculated jointly with the average $P-T$ method (Powell \& Holland 1994). For samples of the garnet-cordierite diatexite, it is considered that garnet, cordierite, sillimanite, biotite, orthoclase, plagioclase and quartz are the paragenesis of the metamorphic peak and that $\mathrm{H}_{2} \mathrm{O}$ was in excess $\left(a_{\mathrm{H} 2 \mathrm{O}}=1\right)$. Values of $6.6 \mathrm{kbar}$ and $850^{\circ} \mathrm{C}$ are calculated for

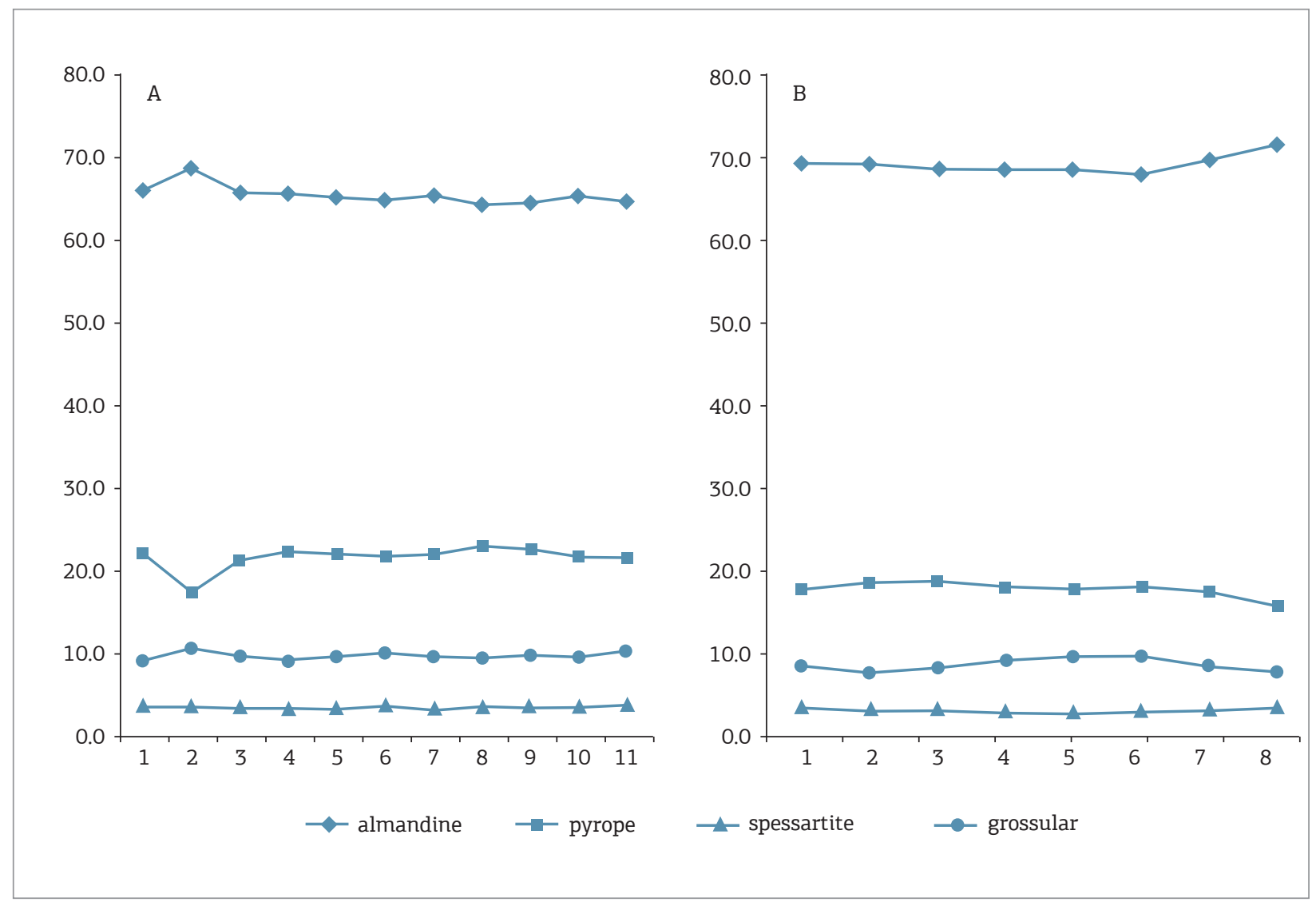

Figure 9. Garnet composition along traverses in selected grains of felsic granulite. (A) RF-03 e (B) RF-16. 
the RF-1 and RF-6 samples, with values somewhat higher for $\mathrm{RF}-24,6.7 \mathrm{kbar}$ and $880^{\circ} \mathrm{C}$. There is not much difference in results if pressure and temperature are calculated separately or together, in this last case using the average $P-T$ method (Tab. 3). It is not possible to calculate pressure or temperature if sillimanite is excluded from the mineral paragenesis.

For the felsic granulite, unrealistic values of $T$ higher than $1000^{\circ} \mathrm{C}$ are calculated when the rock is considered saturated with water. Several calculations are made with different $\mathrm{H}_{2} \mathrm{O}$ activity values, and the calculations made with $a_{\mathrm{H} 2 \mathrm{O}}=0.3$ yielded calculated temperature as $850^{\circ} \mathrm{C}$, similar to the values calculated for the garnet-cordierite diatexite. The $a_{\mathrm{H} 2 \mathrm{O}}$ values do not influence in pressure calculation and values around $6.7 \mathrm{kbar}$ are calculated (Tab. 3).

The $P-T$ calculations are also made with the average $P-T$ method with THERMOCALC, pressure and temperature being calculated at the same time when it is possible to evaluate the correlations between those intensive variables. When the correlation factor is high, close to 1, it indicates that there is a strong dependence of the results obtained for pressure and temperature.

For the garnet-cordierite diatexite, the calculated results are independent of the employed method. Calculations of pressure and temperature made separately or using the average $P$ - $T$ method produced similar values within uncertainties. However, the average $P$ - $T$ method yielded high correlation, larger uncertainties, and this means that if the calculated temperature is reliable, calculated pressure is reliable as well, but the reverse is also true. From a statistical point of view, the results are valid, reliable and interesting because if temperature and pressure are calculated separately the results are very close to the ones produced by the average $P-T$ method, and the high correlation indicates the good quality of the results obtained in the investigated rocks (Tab. 3).

For the felsic granulite, the calculations with the average $P-T$ method are quite dependent on $a_{\mathrm{H} 2 \mathrm{O}}$, but the best results, from a statistical point of view, are obtained with $a_{\mathrm{H} 2 \mathrm{O}}$ values of 0.3 , because the smallest uncertainties are calculated (Tab. 3). Furthermore, results are similar to the conditions in which temperature and pressure are calculated separately and are also similar to those calculated for the cordierite-garnet diatexite samples.

The thermobarometric calculation with the orthopyroxene-garnet pair, using the calibrations of Harley and Green (1982) and Harley (1984a, b) produces consistently lower temperatures and much higher pressures than THERMOCALC.

Table 3. Calculated pressure and temperature values with THERMOCALC, using the following methods, average pressure, average temperature, and average pressure-temperature.

\begin{tabular}{|c|c|c|c|c|c|c|c|}
\hline Sample & Rock & P (kbar) & \pm & $\mathrm{T}\left({ }^{\circ} \mathrm{C}\right)$ & \pm & Correlation & $a_{\mathrm{H} 2 \mathrm{O}}$ \\
\hline RF-1 & diatexite & 6.5 & 0.50 & 850 & 31 & & 1.0 \\
\hline RF-1 (aP-T) & & 6.6 & 0.80 & 855 & 55 & 0.80 & 1.0 \\
\hline RF-6 & diatexite & 6.6 & 0.50 & 837 & 29 & & 1.0 \\
\hline RF-6 (aP-T) & & 6.8 & 0.90 & 856 & 58 & 0.90 & 1.0 \\
\hline RF-24 & diatexite & 6.7 & 0.50 & 881 & 29 & & 1.0 \\
\hline RF-24 (aP-T) & & 7.4 & 0.80 & 904 & 59 & 0.83 & 1.0 \\
\hline $\mathrm{RF}-16$ & granulite & 6.7 & 1.13 & 1,046 & 63 & & 1.0 \\
\hline \multirow[t]{3}{*}{ RF-16 (aP-T) } & & 9.4 & 1.80 & 1,094 & 84 & 0.56 & 1.0 \\
\hline & & 6.7 & 1.30 & 920 & 49 & & 0.5 \\
\hline & & 6.8 & 1.10 & 858 & 48 & & 0.3 \\
\hline \multirow[t]{3}{*}{ RF-16b } & granulite & 6.8 & 1.10 & 1,037 & 63 & & 1.0 \\
\hline & & 6.7 & 1.30 & 925 & 48 & & 0.5 \\
\hline & & 6.8 & 1.10 & 851 & 43 & & 0.3 \\
\hline \multirow[t]{2}{*}{$\mathrm{RF}-3$} & granulite & 7.0 & 1.20 & 895 & 46 & & 0.5 \\
\hline & & 7.1 & 1.20 & 808 & 45 & & 0.3 \\
\hline RF-3 (aP-T) & & 5.8 & 1.20 & 768 & 45 & 0.48 & 0.3 \\
\hline
\end{tabular}

*Sample RF-16b is the same as RF-16, however calculations are made with grains from another field in the same thin section. P: pressure; T: temperature; aP-T: average pressure-temperature. 
For RF-16 sample, temperature calculated values of 730 and $754^{\circ} \mathrm{C}$ are obtained with the Harley (1984b) calibration, using two pairs of garnet and orthopyroxene. For the same pairs, pressure values of 13.6 and $14.0 \mathrm{kbar}$, and 13.5 , and 12.8 kbar are calculated, respectively, with Harley (1984a) and Harley and Green (1982) calibrations. For RF-3 sample, one garnet and two orthopyroxene grains were used in $P-T$ calculations, resulting in calculated temperatures of 785 and $776^{\circ} \mathrm{C}$, with the same garnet core and each of orthopyroxene cores analyses. The calculated pressure using the same sets of analyses resulted in 16.7 and $15.0 \mathrm{kbar}$, and 14.0, and 15.4 kbar, using the Harley (1984a) and Harley and Green (1982) calibrations (Tab. 4).

The results calculated with compositions of the garnet-orthopyroxene pair are discrepant from the ones produced by THERMOCALC and are also not consistent with those observed in experimental investigations with parageneses containing cordierite, whose stability is not higher than 10-11 kbar (e.g. Hensen, 1971). The exaggerated pressure results of calculations are controlled by the low concentration of $\mathrm{Al}_{2} \mathrm{O}_{3}$ in orthopyroxene, since the calibrations are designed for rocks in which orthopyroxene is aluminum-rich, with concentrations greater than 6 to $8 \%$.

Pressure calculation using the garnet-quartz-plagioclase-pyroxene barometer is made using three different calibrations (Newton \& Perkins 1982; Perkins \& Chipera 1985; Eckert et al. 1991). Thermodynamic and experimental calibrations are available for the barometer, involving orthopyroxene (GAPES) or clinopyroxene (GADS) in the following reactions:

grossular +2 pyrope +3 quartz $=3$ anorthite +3 enstatite (GAPES)

2 grossular + pyrope +3 quartz $=3$ anorthite +3 diopside (GADS)

The Newton and Perkins (1982) calibration is thermodynamic and can be used with either ortho- or clinopyroxene, both treated as ideal solid solutions. The non-ideality in garnet solid solution is attributed to grossular-pyrope binary, considered symmetrical (regular model), with

Table 4. Calculated pressure and temperature values using garnet-orthopyroxene pair from felsic granulite.

\begin{tabular}{l|c|c|c}
\hline Sample & $\boldsymbol{P}(\mathbf{k b a r})^{*}$ & $\mathbf{P}(\mathbf{k b a r})^{* *}$ & $\mathbf{T}\left({ }^{\circ} \mathbf{C}\right)^{* * *}$ \\
\hline RF-16 (pair 1) & 13.6 & 14.0 & 730 \\
\hline RF-16b (pair 2) & 13.5 & 12.8 & 754 \\
\hline RF-3 $\left(\mathrm{Opx}^{1}\right)$ & 16.7 & 15.0 & 785 \\
\hline RF-3 $\left(\mathrm{Opx}^{2}\right)$ & 15.4 & 14.0 & 776 \\
\hline
\end{tabular}

*Harley (1984a); **Harley \& Green (1982); ${ }^{* * * H a r l e y ~(1984 b) ; ~ P: ~ p r e s s u r e ; ~}$ T: temperature.
Margules parameter $\mathrm{W}_{\mathrm{CaMg}}$ of $3300 \pm 1.5 \mathrm{~T}(\mathrm{~K})$ calories/mole. Plagioclase is treated as non-ideal asymmetric solid solution (sub-regular model), with values for the Margules parameters of $\mathrm{W}_{\mathrm{An}}=2095 \mathrm{cal}$ and $\mathrm{WAB}=$ $6746 \mathrm{cal}$. The calculated pressure with GAPES is considered the most reliable and results in values about $2 \mathrm{kbar}$ higher than those calculated with GADS. Uncertainties of $1.5 \mathrm{kbar}$ are estimated for GAPES and $1.6 \mathrm{kbar}$ for GADS. The authors suggest that an empirical adjustment of $-0.6 \mathrm{kbar}$ for GAPES and +1.6 for GADS should be made. Perkins and Chipera (1985) presented another GAPES thermodynamic calibration, involving the reactions of $\mathrm{Mg}$ and Fe end-members. The first is a calibration in the CMAS system $\left(\mathrm{CaO}, \mathrm{MgO}, \mathrm{Al}_{2} \mathrm{O}_{3}, \mathrm{SiO}_{2}\right)$, using measurements of the thermodynamic properties of the involved end-members. The second calibration is based on experimental data available (Bohlen et al. 1980, 1983) for the CFMAS system $\left(\mathrm{CaO}, \mathrm{FeO}, \mathrm{Al}_{2} \mathrm{O}_{3}, \mathrm{SiO}_{2}\right)$. The plagioclase activity model developed by Newton and Perkins (1982) is used; orthopyroxene is considered as an ideal solid solution; garnet solid solution is treated with a quaternary model, proposed by Ganguly and Saxena (1984). The application of $\mathrm{Mg}$ end-member reaction is not recommended for Fe-rich rocks $(\mathrm{Fe} /(\mathrm{Fe}+\mathrm{Mg})>0.5)$. The uncertainty is estimated to be $\pm 1 \mathrm{kbar}$. The pressure calculated from the $\mathrm{Mg}$ end-member reaction produces higher values than from the Fe end-member calibration and they are also higher than values produced by the calibration of Newton and Perkins (1982). Eckert et al. (1991) presented an experimental and thermodynamic calibration based on redetermination of enthalpy of GAPES and GADS reactions, using calorimetry to replace the one used in the equation of Newton and Perkins (1982). Also, the activity models of Newton and Perkins (1982) for garnet and plagioclase are adopted, while pyroxene is treated as ideal solid solution. Uncertainties of \pm 1.55 kbar to GAPES and \pm 1.90 kbar to GADS were signed.

The application of GAPES barometer for felsic granulite samples RF-3 and RF-16 results in values between 8 and $9 \mathrm{kbar}$ (Tab. 5). The calculated pressure values are 1 to $1.5 \mathrm{kbar}$ higher than the ones calculated with THERMOCALC, but within the stability field of cordierite observed in the associated garnet-cordierite diatexite, and are compatible within the uncertainty range when the correction of $-0.6 \mathrm{kbar}$ is applied, within the uncertainty range.

The calculated $P-T$ conditions, about $7 \mathrm{kbar}$ and $850{ }^{\circ} \mathrm{C}$, are within the granulite facies conditions, if a minimum temperature of $800^{\circ} \mathrm{C}$ is considered as the lower limit as suggested by Pattison et al. (2003). Such conditions are compatible with the stability fields of orthopyroxene, present in the felsic granulite, cordierite, which is extremely abundant 
Table 5. Calculated pressure values using a garnet-orthopyroxene-plagioclase-quartz (GAPES) barometer for felsic granulite $\left(850^{\circ} \mathrm{C}\right.$ is the reference temperature).

\begin{tabular}{l|c|c|c|c|c}
\hline sample & $\boldsymbol{P}(\mathbf{k b a r})^{*}$ & $\boldsymbol{P}(\mathbf{k b a r})^{* *}$ & $\boldsymbol{P}(\mathbf{k b a r})^{* * *}$ & $\boldsymbol{P}(\mathbf{k b a r})^{* * * *}$ & $\boldsymbol{P}(\mathbf{k b a r})^{* * * * *}$ \\
\hline RF-16 & 8.06 & 7.46 & 7.99 & 8.27 \\
\hline RF-3 & 8.63 & 8.03 & 8.50 & 8.01 \\
\hline
\end{tabular}

${ }^{*}$ Newton \& Perkins (1982); ${ }^{* *}$ Newton \& Perkins (1982) with empiric correction of -0.6 kbar; ${ }^{* * *}$ Perkins \& Chipera (1985) - Mg end member calibration; ${ }^{* * * *}$ Perkins e Chipera (1985) - Fe end member calibration; ${ }^{* * * *}$ Eckert et al. (1991); P: pressure.

in the garnet-cordierite diatexite, and sillimanite, the $\mathrm{Al}_{2} \mathrm{SiO}_{5}$ polymorph observed in these rocks.

From the mineralogical perspective, the felsic granulite has a composition equivalent to a greywacke, similar to the one modeled by Johnson et al. (2008, figure $1 \mathrm{~d}$ of that paper), and given the calculated $P-T$ conditions, the same paragenesis is observed, which is formed together with a production of 10 to $15 \%$ partial melting, close to exhaustion of biotite and just above the cordierite stability field for this bulk composition. This is in agreement with field and petrographic observation, as thin leucosome veins are observed within the felsic granulite (Figs. 6A and 6B). Therefore, the metamorphic peak conditions are achieved crossing biotite breakdown/melting reaction, producing a granulite residue and orthopyroxene-bearing melt, now represented by leucosome. The low amount of partial melting is constrained by low fertility of this kind of protolith, as well as by low amount of available water.

Larger amounts of leucosome, observed in association with the garnet-cordierite diatexite, are compatible with calculated $P-T$ conditions, if it is considered that the following reaction was crossed during the progressive stage of rock $P-T$ path: sillimanite + biotite + quartz $=$ garnet + cordierite + orthoclase + liquid, in the KFMASH system, although plagioclase might be added as reactant as well (Spear et al. 1999). Through the partial melting modeling of pelite, or adding plagioclase to have an aluminum-rich greywacke as protolith, the rock can cross this reaction at the calculated P-T conditions, producing, at least, $50 \%$ of partial melt and a residue dominated by cordierite and garnet, devoid of sillimanite, with minor amounts of or no biotite, as suggested by pseudosections calculated with sedimentary bulk compositions (White \& Powell 2002; White et al. 2007; Johnson et al. 2008).

The genesis of felsic granulite and garnet-cordierite diatexite is deeply associated with partial melting reactions, production of a melt phase, which was segregated, leaving behind different kinds of residues that, in turn, were controlled by different bulk compositions. The more fertile composition produced large amounts of melt and a residue constituted of different amounts of cordierite and garnet from a pelite or an aluminum-rich greywacke. In any case, the protolith was richer in biotite than in sillimanite, since the latter mineral is observed only as an inclusion in cordierite or garnet, but never in the matrix. The less fertile felsic granulite produced a smaller amount of melt, evidenced by thin layers of orthopyroxene-bearing leucosome. In both cases, independently of the amount of generated melt, a fair portion of it was segregated and, probably, lost, contributing to the generous magmatism observed in the area. This inference relies on the fact that, in both rock types, orthopyroxene, cordierite or garnet are preserved and only a small amount of grains present retrogression textures, as rim replacement by biotite-bearing symplectite. This kind of reaction texture is interpreted as the result of retrograde reaction between peritectic phases and entrapped melt (Kriegsman \& Hensen 1998). If no melt is lost, the peritectic phases should be completely consumed during cooling, as the stoichiometry ratio of produced phases along the progressive path is not changed. Therefore, all peritectic phases would react back with melt to produce reactant phases, as biotite, sillimanite, quartz and feldspars (White \& Powell 2002). If fractions of produced melt are segregated and lost, only partial retrogression occurs, and preservation of peritectic phases is possible if all, or at least most, melt is segregated from the residue (Moraes et al. 2002; White \& Powell 2002).

Considering an average crust with an intermediate bulk composition, between andesite and tonalite (Wedepohl 1991), with density varying between 2.6 and $2.7 \mathrm{~g} / \mathrm{cm}^{3}$, a depth of 25 to $26.5 \mathrm{~km}$ is needed to produce a lithostatic pressure of $7 \mathrm{kbar}$, of middle crust setting, leading to a gradient of $32-34^{\circ} \mathrm{C} / \mathrm{km}$, which is a little higher than typical barrovian metamorphism, requiring a higher thermal gradient that can be produced by incoming heat of contemporaneous granite intrusions.

\section{DISCUSSION}

\section{Thermobarometry}

The calculations made with THERMOCALC used the whole metamorphic peak mineral assemblage, and produced the most reliable $P-T$ results, as they are more consistent 
and have lower uncertainties, when compared to conventional methods of thermobarometry. The most consistent $P-T$ results for the investigated felsic granulites are $7 \mathrm{kbar}$ and $850^{\circ} \mathrm{C}$, calculated with low water activity, $a_{\mathrm{H} 2 \mathrm{O}}=0.3$. The results are in agreement with $P-T$ calculations made for the garnet-cordierite diatexite. These conditions are compatible with the orthopyroxene, cordierite and sillimanite stability fields for protoliths, respectively, of greywacke/granite and bulk pelite compositions. It is interesting to note that an optimum value of water activity could be found for the felsic granulite, as the lowest uncertainties and coherent $P-T$ values were calculated, but for the garnet-cordierite diatexite, water activity radically changes the values of calculated temperature, but does not influence too much the results of calculated pressure.

The $P-T$ results obtained with conventional methods of thermobarometry, using garnet and orthopyroxene compositions, are somewhat ambiguous, either because low temperatures are calculated and are not compatible with the orthopyroxene stability field, or due to calculated high pressures, which are outside the stability field of cordierite/sillimanite, present in the most abundant rock in the area, the garnet-cordierite diatexite. The calibrations done for the orthopyroxene and garnet pair, as thermometer or barometer, are based, respectively, on Fe-Mg and tschermak exchanges. Some were designed to work better for rocks where orthopyroxene presents high concentrations of aluminum. However, even the barometer calibrations are very sensitive to later $\mathrm{Fe}-\mathrm{Mg}$ exchange, producing results that are not valid without corrections (Pattison \& Bégin 1994; Fitzsimons \& Harley 1994). Some of the problems may be related to expressions derived from experiments that were not truly reversed, producing imprecise expressions to calculate pressure and temperature (Pattison 1994). Although both calibrations of the garnet-orthopyroxene barometer failed to produce reliable results, calculations run with the GAPES barometer yielded, within the uncertainties, results consistent with the ones calculated with THERMOCALC and are considered to have geological value.

$P-T$ calculation for granulites using either conventional thermobarometry or THERMOCALC can result in equivalent results, the reliability of which experiences the same constraints, i.e. late re-equilibrium between $\mathrm{Fe}$ and $\mathrm{Mg}$ or consumption of these phases due to the presence of trapped melt (Spear 1991; Spear \& Florence 1992; White \& Powell 2002, 2010; Moraes et al. 2002; Pattison et al. 2003). For migmatites this might be an even harder and complex situation to investigate, because in many cases it becomes difficult to evaluate, based on the texture, if all phases were in chemical equilibrium during metamorphic peak, especially plagioclase and biotite, which can be crystallized from the trapped melt, but due to some late deformation, might look in textural equilibrium with other phases, which did not really coexist during the metamorphic peak. This problem can be accessed using a pseudosection that is a map of all mineral assemblages allowed by a determined bulk composition, inside a $P-T$ window. However, the beauty of the method is also its doom, as it is necessary to know the original protolith bulk composition, which for a migmatite is difficult, or even impossible. Therefore, it is necessary to use a hypothetical bulk composition or try to find a rock that is the low-grade equivalent of migmatite.

Sillimanite is clearly in petrographic disequilibrium with the metamorphic peak mineral assemblage. However, no good $P$ - $T$ calculation was possible without this mineral, given that it helps to balance and produce a larger amount of reactions, helping to produce a set of linear independent reactions. Therefore, all P-T calculations done for the garnet-cordierite diatexite must be taken as, at least, suspicious. Adding sillimanite to the mineral assemblage will force THERMOCALC to calculate a point over the univariant KFMASH reaction or inside a divariant field in the NCKFMASH field. This produces a minimum $P-T$ condition for the mineral assemblage of the garnet-cordierite diatexite. Consequently, all $P-T$ calculations done for the felsic granulite produced more reliable results.

\section{Tectonic implications of obtained results}

As shown above, the study region underwent metamorphism and partial melting in a crust with a thermal gradient of $32-34^{\circ} \mathrm{C} / \mathrm{km}$, with metamorphic peak achieved at depths of 25 to $26.5 \mathrm{~km}$. These conditions are somewhat higher than typical barrovian metamorphism, and probably imply a hot middle portion of thickened continental crust or lower portions of thinned crust. The mid crust is a more favorable tectonic setting, as studied rocks are inserted into the Araçuaí Orogen, a hot orogen in which several episodes of granite magmatism are recorded. It started with the G1 pre-colisional suite, with ages spanning from 630 to $585 \mathrm{Ma}$; the G2 and G3 suites are constituted of S-type granites, with ages between 585 and $535 \mathrm{Ma}$, and are coeval to high-grade metamorphism, which involved formation of granulites and diatexites, investigated in this research; two post-collisional granite suites known as G4 suite also of S-type granite, and G5 suite, made of charnockites, both forming high sugar-loafs in the region, crystallized between 520 and $490 \mathrm{Ma}$ (see Gradim et al. 2014 and references therein). With such evolution, from granulite facies metamorphic peak to intrusion of later suites, including very hot charnockite magmas, a time span of almost $100 \mathrm{Ma}$ is needed, and along all this time the mid crust was necessarily either hot or heated, at 
least twice, for metamorphic peak, and then for the formation of hot post-collisional granite magmas.

A significant portion of granulites is formed in middle to lower continental thickened crust in collisional tectonic settings, similar to the roots of the Himalayas (England \& Thompson 1984; Ellis 1987; Harley 1989, 1992; Ashwall et al. 1992; Collins 2002; Jamieson et al. 2004). However, a major problem identified in such a tectonic setting is the lack of enough heat produced only by decay of radioactive elements, and another complimentary heat source is needed (England \& Thompson 1984; Ellis 1987; Harley 1989, 1992; Ashwall et al. 1992; Jamieson et al. 1998). Several models are available: underplating of hot basalt magma (Wells 1980; Elllis 1987; Bohlen 1987, 1991; Bohlen \& Mezger 1989); an additional layer of continental crust material rich in radioactive elements (TARM), subducted at mantle level (Jamieson et al. 1998); removal of a thermal boundary layer due to convection of the asthenosphere, causing a huge thermal anomaly at the bottom of the orogen that will be followed by high-grade metamorphism, rising topography, extensional collapse and granite and basalt magmatism (England 1994). Modern techniques are able to take into account a larger number of parameters, used to generate complex mathematical models, which are closer to real situations, presenting more consistent results than the early ones. Modeling for the Himalayan Orogeny solved the problem of heat source starting with a pre-heated crust and overthrusting hot migmatites over the down going rocks that were being heated due to collision, leading to partial melting and granulite facies conditions, with peak temperature over $900^{\circ} \mathrm{C}$ that are easily produced within the mountain chain (Jamieson et al. 2004). Nevertheless, in all the models, granulite facies conditions are achieved at pressure greater than $8 \mathrm{kbar}$ and this is not in agreement with calculated $P-T$ conditions for the investigated rocks and an alternative model must be considered, as well as a way to heat up the crust twice in the same tectonic event.

It is possible to pre-heat the continental crust in a backarc basin setting due to the movement of shallow mantle convection currents. Subsequent closure of the basin establishes an ideal setting to produce granites, migmatites and granulites, under medium pressure conditions (Hyndman et al. 2005). This model was proposed with great success to explain the evolution of the Araçuaí Orogen (Gradim 2013; Gradim et al. 2014). This type of tectonic setting encompasses the ideal characteristics for generation of most of the observed geology of the Araçuaí Orogen. The back-arc closure results in the edification of the orogen, induced by continental collision, followed by high-grade metamorphism, partial melting and granite magmatism, and later followed by the gravitational collapse of the orogen (Pedrosa-Soares et al. 2007). After this, the crust should be submitted to erosion and cooling in order to achieve isostatic equilibrium. This imposes a drawback to the model, as no heat source will be available to produce the younger G4 and G5 suites, especially the last one constituted of very hot charnockite magma. Another heating event is needed. What is the cause for a new heating event to produce such important hot magmatism?

The tectonic switching model is based on alternating regimes of extension and contraction of continental crust, induced by changes in the angle of slab subduction that, in turn, is controlled by intermittent arrival of buoyant oceanic plateaus (Collins 2002). This is almost the base for the model proposed by Hyndman et al. (2005). However, as tectonic switching may happen more than once, it offers the possibility of more than one heating stage in the same orogen. In this model, cycles of flat to steep subduction result in episodes of crustal thickening followed by extension, and more than one event of high-grade metamorphism and partial melting might be generated.

The tectonic switching model may enhance the Araçuaí Orogen evolution. The closure of a basin with a pre-heated crust producing high-grade metamorphism and partial melting (G2 and G3 suites) during crustal thickening is followed by flat subduction, induced by basalt plateau entering into the subduction zone that will cause a stage of tectonic quiescence. After the plateau is subducted, the subduction slab changes to a steeper regime, causing tectonic roll-back, crust extension, advection of hot asthenosphere that during decompression produces basaltic magma and a thermal anomaly at the base of the continental crust, after the first main metamorphism and magmatism event. A new highgrade metamorphic event associated with extensive granite and charnockite magma production takes place in a younger period, represented by the G4 and G5 suites. The effect of this later extension caused by tectonic switching should not be different from a gravitational collapse produced by removal of the thermal boundary layer as proposed in other models (England 1994). The advantage of tectonic switching is the possibility of a new heating event later in the orogen evolution, producing extensive magmatism, with contribution from mantle and crustal sources. It also should produce another high-grade metamorphic event, with the same age as G4 and G5 suites, which is not reported so far, but might be a nice possibility for future investigations.

Although the tectonic switching model may explain the time spam between main metamorphism/G2-G3 Granite Suites and later G4 and G5 Suites, it requires a longer period of subduction. As the Araçuaí Orogen is semi-confined, the nutcracker tectonic model was proposed and it explains most of the features observed (Alkmim et al. 2006), however it 
does not require extensive subduction of oceanic crust and it opposes with the tectonic switching. Another point that must be evaluated is how far the change in the subduction angle can affect the inner portions of the orogen, because rocks of the Jequitinhonha Complex lay on the ensialic portion of the Araçuaí Orogen, in its innermost portion. Although the tectonic switching model can explain some features, it is not perfect, but it is an interesting option to be further investigated.

\section{CONCLUSIONS}

In southern Bahia, granulites and migmatites of the Jequitinhonha Complex constitute an important portion of the Araçuaí Orogen (Sampaio et al. 2004). These rocks underwent granulite facies metamorphism with metamorphic peak conditions of $850^{\circ} \mathrm{C}$ and 7 kbar. Assorted methods to calculate $P$ - $T$ conditions were used and optimal thermobarometry using THERMOCALC produced a more consistent set of results. This method also brings the advantage to be able to investigate the presence, composition and influence of the fluid phase. For the garnet-cordierite diatexite, a water rich fluid produces better results, but for the felsic granulite a fluid with water activity of 0.3 yielded the most consistent statistical values for pressure and temperature. These results are also compatible with the stability field of the mineral assemblage constituted of garnet + cordierite + orthoclase + quartz coexisting with a melt phase, as well as with orthopyroxene + garnet + plagioclase + quartz, respectively, in garnet-cordierite diatexite and felsic granulite. Even if the value of $8 \mathrm{kbar}$, produced by conventional barometry, is used, it is also compatible with observed mineral assemblages. These $P-T$ conditions are also in agreement with the KFMASH melting reaction of sillimanite + biotite, in presence of quartz and feldspars, which was the reaction crossed by pelites to produce the garnet-cordierite diatexite that dominates the geology of this region (Sampaio et al. 2004).

The calculated $P-T$ conditions are compatible with tectonic settings of the middle crust with high geothermal gradient, which matches either a magmatic arc setting or portions of back-arc basin, as proposed before for these rocks (Noce et al. 2004; Pedrosa-Soares et al. 2006; Silva et al. 2008; Roncato 2009; Gradim 2013; Gradim et al. 2014). The tectonic switching model enhances the Araçuaí Orogen evolution in comparison with previous proposals, as it can explain the time gap between main metamorphism and associated G2 suite with later and hot G4 and G5 suites.

Acknowledgments: The authors thank the agreement CAPES-COFECUB, Brazil-France, 624/09, which financed the present research and CBPM, Companhia Bahiana de Pesquisa Mineral, for the assistance during the fieldwork and preparation of samples. R.A. Fuck thanks $\mathrm{CNPq}$ for research grants 303341/2011-4 and 573713/2008-1 INCT-ET. We also thank the two reviewers that made valuable comments on the first draft of this paper and the editors Umberto G. Cordani and Fernando F. Alkmin for their work and efforts, which improved the final version.

\section{REFERENCES}

Alkmim F. F., Marshak S., Fonseca M. A. 2001. Assembling West Gondwana in the Neoproterozoic: clues from the São Francisco Craton region, Brazil. Geology, 29: 319-322.

Alkmim, F. F., Marshak, S., Pedrosa-Soares, A. C., Peres, G .G., Cruz, S. C. P., Whittington, A. 2006. Kinematic evolution of the Araçuaí-West Congo orogen in Brazil and Africa: Nutcracker tectonics during the Neoproterozoic assembly of Gondwana. Precambrian Research, 149(1-2): 43-64.

Alkmim F. F., Pedrosa-Soares A. C., Noce C. M., Cruz S. C. P. 2007. Sobre a Evolução Tectônica do Orógeno Araçuaí-Congo Ocidental. Geonomos, 15(1): 15-43.

Almeida F. F. M. 1977. O Cráton do São Francisco. Revista Brasileira de Geociências, 7(4): 349-364.

Almeida, F. F. M. \& Litwinski, N. 1984. Província Mantiqueira - Setor Setentrional. In: Almeida, F. F. M. \& Hasui, Y. (eds) O Pré-Cambriano do Brasil. São Paulo, Edgard Blücher, p. 282-307.

Almeida F. F. M., Hasui Y.; Brito Neves B. B., Fuck R. A. 1977. Províncias estruturais brasileiras. In: VIII Simpósio de Geolologia do Nordeste. Atas, Campina Grande, p. 363- 391.
Almeida F. F. M., Hasui Y., Brito Neves B. B., Fuck R.A. 1981. Brazilian structural provinces: An introduction. Earth-Science Reviews, 17(1): 1-29

Aracema L. W., Neves A. C., Ferreira J. C., Pedrosa-Soares A. C., Lobato L. M. \& Noce C. M. 2000. Novas evidências de remanescentes oceânicos na Faixa Araçuaí: as rochas meta-ultramáficas de São José da Safira. Geonomos, 8 (1): 55-61.

Ashwall L. D., Morgan P., Hoish T. D. 1992. Tectonics and heat sources for granulite metamorphism of supracrustal-bearing terranes. Precambrian Research, 55: 525-538.

Baldwin J. A., Powell R., Brown M., Moraes R., Fuck R. A. 2005. Modeling of mineral equilibria in ultrahigh-temperature metamorphic rocks from the Anápolis-Itauçu Complex, central Brazil. Journal of Metamorphic Geology, 23: 511-531.

Belém, J. 2006. Caracterização Mineralógica, Física e Termobarométrica de Minérios de Grafita da Província Grafítica Bahia-Minas. MS Dissertation, Instituto de Geociências, Universidade Federal de Minas Gerais, Belo Horizonte, 164 p. 
Berman R. G. 1988. Internally-consistent thermodynamic data for minerals in the system $\mathrm{K}_{2} \mathrm{O}-\mathrm{Na}_{2} \mathrm{O}-\mathrm{CaO}-\mathrm{MgO}-\mathrm{FeO}-\mathrm{Fe}_{2} \mathrm{O}_{3}-\mathrm{Al}_{2} \mathrm{O}_{3}-\mathrm{SiO}_{2}-$ $\mathrm{TiO}_{2}-\mathrm{H}_{2} \mathrm{O}-\mathrm{CO}_{2}$. Journal of Petrology, 29: 445-522.

Bohlen S. R. 1987. Pressure-temperature time paths and a tectonic model for the evolution of granulites. Journal of Geology, 95: 617-632

Bohlen S. R. 1991. On the formation of Granulites. Journal of Metamorphic Geology, 9: 223-229.

Bohlen S.R., Essene E. J., Boettcher A. L. 1980. Reinvestigation and application of olivine-quartz-orthopyroxene barometry. Earth and Planettary Sciences Letters, 47: 1-10.

Bohlen S.R. \& Mezger K. 1989. Origin of granulite terranes and the formation of the lowermost continental crust. Science. 244: 326-329.

Bohlen S. R., Wall V. J., Boettcher A. L. 1983. Experimental investigation and application to garnet granulite equilibria. Contributions to Mineralogy and Petrology, 83: 52-61.

Brito Neves, B. B. \& Cordani, U. G. 1991. Tectonic evolution of South America during the Late Proterozoic. Precambrian Research, 53: $23-40$

Collins, W. J. 2002. Hot Orogens, tectonic switching, and creation of continental crust. Geology, 30: 535-538.

Cordani, U. G. 1973. Evolução Geológica Pré-Cambriana da Faixa Costeira do Brasil, entre Salvador e Vitória. Livre Docência Thesis. Instituto de Geociências, Universidade de São Paulo, São Paulo 98 p.

Cruz S., Alkmin F. F., Silva A. J. P., Teixeira L. R., Pedrosa Soares, A. C., Corrêa Gomes, L. C., Souza, J. S., Leal A. B. M. 2012. Orógeno Araçuaí. Capítulo X. In: Barbosa J. S. F. (coord.) Geologia da Bahia - Pesquisa e Atualização. Salvador, CBPM, Série Publicações Especiais. vol. 2: 131-178.

Eckert J. O., Newton R. C., Kleppa O. J. 1991. The DH of reaction and recalibration of garnet-pyroxene-plagioclase-quartz geobarometers in the CMAS system by solution calorimetry. American Mineralogist, 76: $148-160$

Ellis D. J. 1987. Origin and evolution of granulites in normal and thickened crusts. Geology, 15: 167-170.

England P. C. 1994. Convective removal of thermal boundary layer of thickened continental lithosphere: a brief summary of causes and consequences with special reference to the Cenozoic tectonics of the Tibetean Plateau and surrounding regions. Tectonophisics, 223: 67-73.

England, P. C. \& Thompson, A. B. 1984. Pressure-temperaturetime path of regional metamorphism I. Heat transfer during evolution of regions of thickened continental crust. Journal of Petrology, 25: 894-928.

Fitzsimons, I. C. W. \& Harley, S. L. 1994. The influence of retrograde cation exchange on granulite P-T estimates and a convergence technique for the recovery of peak metamorphic conditions. Journal of Petrology, 35: 543-576.

Frost, B. R. \& Chaco, T. 1988. The granulite uncertainty principle: Limitations on thermobarometry in granulites. Journal of Geolology, 97: $435-450$

Fyfe, W. S. 1973. The granulite facies, partial melting and the Archaean crust. Philosophical Transactions of the Royal Society of London, 273A: 457-461.

Ganguly, J. \& Saxena, S. K. 1984. Mixing properties of aluminosilicate garnets: Constraints from natural and experimental data, and applications to geothermo-barometry. American Mineralogist, 69: 88-97.
Gonçalves-Dias, T., Pedrosa-Soares, A. C., Dussin, I. A., Alkmim, F. F., Caxito, F. A., Silva, L. C. Noce. C. M. 2011. Idade máxima de sedimentação e proveniência do Complexo Jequitinhonha na áreatipo (Orógeno Araçuaí): primeiros dados U-Pb (LA-ICP-MS) de grãos detríticos de zircão. Geonomos, 19: 121-130.

Gradim C. T. 2013. Complexo Nova Venécia e magmatismo associado, Orógeno Araçuaí, Estado do Espírito Santo. MS Dissertation, Instituto de Geociências, Universidade Federal de Minas Gerais, Belo Horizonte, 96 p.

Gradim, C. T., Roncato, J., Pedrosa-Soares, A. C., Cordani, U. G., Dussin, I., Alkmim, F. F., Queiroga, G., Jacobsohn, T., Silva L. C., Babinski, M. 2014. The hot back-arc zone of the Araçuaí orogen, Eastern Brazil: from sedimentation to granite generation. Brazilian Journal of Geology, 44: 155-180.

Harley S. L 1984a. An experimental study of the partitioning of the Fe and Mg between garnet and orthopyroxene. Contributions to Mineralogy and Petrology, 86: 359373.

Harley S. L. 1984b. The solubility of alumina in orthopyroxene coexisting with garnet in $\mathrm{FeO}-\mathrm{MgO}-\mathrm{Al}_{2} \mathrm{O}_{3}-\mathrm{SiO}_{2}$ and $\mathrm{Cao}-\mathrm{FeO}-\mathrm{MgO}$ $\mathrm{Al}_{2} \mathrm{O}_{3}-\mathrm{SiO}_{2}$. Journal of Petrology, 25: 665-696.

Harley S. L. 1989. The origins of granulites: a metamorphic perspective. Geological Magazine, 126: 215-247.

Harley S. L. 1992. Proterozoic granulite terranes. Chapter 8. In Condie K.C. (Ed) Proterozoic Crustal Evolution: Developments in Precambrian Geology 10. Amsterdam, Elsevier, p. 301-360.

Harley S. L. 2008. Refining the P-T records of UHT crustal metamorphism. Journal of Metamorphic Geology, 26: 125-154.

Harley, S. L. \& Green, D. H. 1982. Garnet-orthopyroxene barometry for granulites and peridotites. Nature, 300: 697-701

Hartel T. H. D. \& Pattison D. R. M. 1996. Genesis of the Kapuskasing (Ontario) migmatitic mafic granulites by dehydration melting of amphibolite: the importance of quartz to reaction progress. Journal of Metamorphic Geology, 14: 591-612.

Heilbron M., Pedrosa-Soares A. C., Campos Neto, M. C., Silva, L C., Trouw, R. A. J., Janasi, V. C. 2004. A Província Mantiqueira. In: Mantesso-Neto, V., Bartorelli, A., Carneiro, C. D. R., Brito Neves, B. B. (eds.) O Desvendar de um Continente: a Moderna Geologia da América do Sul e o Legado da Obra de Fernando Flávio Marques de Almeida. São Paulo, Beca, p. 203-234.

Hensen, B. J. 1971. Theoretical phase relations involving cordierite and garnet in the system $\mathrm{MgO}-\mathrm{FeO}-\mathrm{Al}_{2} \mathrm{O}_{3}-\mathrm{SiO}_{2}$. Contribution to Mineralogy and Petrology, 33: 191-214.

Holland, T .J. B. \& Powell, R. 1998. An internally-consistent thermodynamic dataset for phases of petrological interest. Journal of Metamorphic Geology, 16, 309-344

Holland, T. J. B. \& Powell, R. 2011. An improved and extended internally consistent thermodynamic dataset for phases of petrological interest, involving a new equation of state for solids. Journal of Metamorphic Geology, 29(3): 333-383.

Hyndman, R. D., Currie, C. A., Mazzotti, S.P. 2005. Subduction zone backarcs, mobile belts, and orogenic heat. Geological Society of America Today, 15: 4-10.

Jamieson, R., Beaumont, C., Pulsack, P., Lee B. 1998. Barrovian regional metamorphism: where's the heat? In: Treloar, P.J. \& O'Brien P. (eds.) What Drives Metamorphism and Metamorphic Reactions? London, Geological Society, Special Publication, 138, p. 23-51.

Jamieson, R. A., Beaumont, C., Medvedev, S., Nguyen, M. H. 2004. Crustal channel flows: 2 . Numerical models with implications for metamorphism in the Himalayan-Tibetan orogen. Journal of Geophysical Research, 109(B6): 06407-B06407. 
Johnson, T. E., White, R. W., Powell, R. 2008. Partial melting of metagreywacke: a calculated mineral equilibria study. Journal of Metamorphic Geology, 26: 837-853.

Kriegsman, L. M. \& Hensen, B. J. 1998. Back reaction between restite and melt: Implications for geothermobarometry and pressuretemperature paths. Geology, 26:1111-1114.

Moraes, R., Brown, M., Fuck, R. A., Camargo, M. A., Lima, T. M. 2002. Characterization and P-T evolution of melt-bearing ultrahightemperature granulites: an example from the Anápolis-Itauçu Complex of the Brasília Fold Belt, Brazil. Journal of Petrology, 43: 1673-1705.

Moraes, R. \& Fuck, R.A. 2000. Ultra-high temperature metamorphism in central Brazil: The Barro Alto Complex. Journal of Metamorphic Geology, 18: 345-358.

Newton, R. C. \& Perkins, D. 1982. Thermodynamic calibration of geobarometers based on the assemblage garnet - plagioclase orthopyroxene (clinopyroxene) - quartz. American Mineralogist, 67: 203-222.

Noce, C. M., Pedrosa-Soares, A. C., Piuzana, D., Armstrong, R. A., Laux, J. H., Campos, C. M., Medeiros, S.R. 2004. Ages of sedimentation of the kinzigitic complex and of a late orogenic thermal episode of the Araçuaí Orogen, northern Espírito Santo State, Brazil: Zircon and monazite U-Pb SHRIMP and ID-TIMS data. Revista Brasileira de Geociências, 34: 587-592.

Noce, C. M., Pedrosa-Soares, A. C., Silva, L. C. \& Alkmim, F. F. 2007. O Embasamento Arqueano e Paleoproterozoico do Orógeno Araçuaí. Geonomos, 15: 17-23.

Pattison, D. R. M. 1994. Are reversed Fe-Mg exchange and solid solution experiments really reversed? American Mineralogist, 79: 938-950.

Pattison D. R. M., \& Bégin, N. J. 1994. Zoning patterns in orthopyroxene and garnet in granulites: implications for geothermometry. Journal of Metamorphic Geology, 12: 387-410.

Pattison D. R. M., Chacko, T., Farquhar, J., McFarlane, C. R. M. 2003. Temperatures of granulite-facies metamorphism; constraints from experimental phase equilibria and thermobarometry corrected for retrograde exchange. Journal of Petrology, 44: 867-900.

Pedrosa-Soares, A.C., Castañeda, C., Queiroga, G., Gradim, C., Belém, J., Roncato, J., Novo, T., Dias, P., Gradim, D., Medeiros, S., Jacobsohn, T., Babinski, M., Vieira, V. 2006. Magmatismo e tectônica do Orógeno Araçuaí no extremo leste de Minas Gerais e norte do Espírito Santo. Geonomos, 14: 97-111.

Pedrosa-Soares, A. C. \& Alkmin, F. F. 2011. How many rifting events preceded the development of the Araçuaí-West Congo orogen? Geonomos, 19: 244-251.

Pedrosa-Soares, A. C., Noce, C. M., Alkmin, F. F., Silva, L. C. S., Babinski, M., Cordani, U. G., Castañeda, C. 2007. Orógeno Araçuaí: Síntese do conhecimento 30 anos após Almeida 1977. Geonomos, 15: 1-16.

Pedrosa-Soares, A. C., Noce, C. M., Wiedemann, C. M., Pinto, C. P. 2001. The Araçuaí-West Congo orogen in Brazil: An overview of a confined orogen formed during Gondwanland assembly. Precambrian Research, 110: 307-323.

Pedrosa-Soares, A.C. \& Wiedemann-Leonardos, C. M. 2000. Evolution of the Araçuaí Belt and its connection to the Ribeira Belt, Eastern Brazil. In: Cordani, U. G., Milani, E .J., Thomaz-Filho, A., Campos, D.A. (eds), Tectonic Evolution of South America. São Paulo, Sociedade Brasileira de Geologia, p. 265-285.

Pedrosa-Soares, A. C. \& Noce, C. M. 1998. Where is the suture zone of the Neoproterozoic Araçuaí-West-Congo orogen In: Conference on Basement Tectonics, 14, Ouro Preto. UFOP, Extended Abstracts, p. 35-37.
Pedrosa-Soares, A. C., Noce, C. M., Vidal, P., Monteiro, R., Leonardos, O. H. 1992. Toward a new tectonic model for the Late Proterzoic Araçuaí (SE Brazil) - West Congolian (SW Africa) Belt. Journal of South American Earth Sciences, 6: 33-47.

Pedrosa-Soares, A. C., Vidal, P., Leonardos, O. H., Brito-Neves, B. B. 1998. Neoproterozoic oceanic remnants in eastern Brazil: Further evidence and refutation of an exclusively ensialic evolution for the Araçuaí-West Congo orogen. Geology, 26: 519-522.

Pedrosa-Soares, A. C., Alkmin, F. F., Tack, L., Noce, C. M., Babinski, M., Silva, L. C., Martins Neto, M. A. 2008. Similarities and differences between the Brazilian and African counterparts of the Neoproterozoic Araçuaí-West Congo orogen. In: Pankhurst R. T., Trouw, R. A. J., Brito Neves, B. B., Wit, M. J. (eds) West Gondwana: Pre-Cenozoic Correlations Across the South Atlantic Region. London, Geological Society, Special Publications, 294, p. 153-172.

Perkins, D. \& Chipera, S. J. 1985. Garnet-orthopyroxene-plagioclasequartz geobarometry: refinements and application to the English River subprovince and the Minnesota River Valley. Contributions to Mineralogy and Petrology, 89: 69-80.

Powell, R. \& Holland, T. J. B. 1994. Optimal geothermometry and geobarometry. American Mineralogist, 79: 120-133.

Powell, R. \& Downes, J. 1990. Garnet porphyroblast-bearing leucosomes in metapelites: mechanisms, phase diagrams, and an example from Broken Hill, Australia. In: Ashworth, J. R., Brown, M. (eds.) High Temperature Metamorphism and Crustal Anatexis. London Unwin Hyman, p. 105-123.

Powell, R., Guiraud, M., White, R.W. 2005. Truth and beauty in metamorphic mineral equilibria: conjugate variables and phase diagrams. Canadian Mineralogist, 43: 21-33.

Powell, R. \& Holland, T. J. B. 1988. An internally consistent dataset with uncertainties and correlations: 3. Applications to geobarometry, worked examples and a computer program. Journal of Metamorphic Geology, 6: 173-204.

Queiroga, G., Pedrosa-Soares, A. C., Noce, C. M., Alkmim, F. F., Pimentel, M. M., Dantas, E., Martins, M., Castañeda, C., Suita, M. T. F., Prichard, H. 2007. Age of the Ribeirão da Folha ophiolite, Araçuaí Orogen: The U $\mathrm{Pb}$ zircon dating of a plagiogranite. Geonomos, 15: 61-65.

Roncato, J. G. 2009. As suítes graníticas tipo-S do norte do Espírito Santo na região das folhas Ecoporanga, Mantena, Montanha e Nova Venécia. MS Dissertation, Instituto de Geociências, Universidade Federal de Minas Gerais, Belo Horizonte, 102 p.

Sampaio, A. R., Martins, A. M., Loureiro, H .C., Arcanjo, J. B., Moraes Filho, J. C., Souza, J. D., Pereira, L. H., Couto, P. A., Santos, R. A., Melo, R. C., Bento, R. V., Borges, V.P. 2004. Projeto Extremo Sul da Bahia: Geologia e Recursos Minerais. Salvador, Companhia Bahiana de Pesquisa Mineral, Série Arquivos Abertos, 19: 52 p.

Sawyer, E. W. 2008. Atlas of Migmatites. Special Publications of The Canadian Mineralogist, vol. 9, 386 p.

Siga, Jr. O. 1986. A Evolução Geotectônica da Porção Nordeste de Minas Gerais com Base em Interpretações Geocronológicas. São Paulo. MS Dissertation, Instituto de Geociências, Universidade de São Paulo, São Paulo, 121 p.

Silva, L. C., McNaughton, N., Armstrong, R., Hartmann, L. \& Fletcher, I. 2005. The Neoproterozoic Mantiqueira Province and its African connections. Precambrian Research, 136: 203-240

Silva, L. C., Pedrosa-Soares, A. C., Teixeira, L., Armstrong, R. 2008. Tonian rift-related, A-type continental plutonism in the Araçuaí Orogen, eastern Brazil: New evidence for the breakup stage of the São Francisco Congo Paleocontinent. Gondwana Research, 13: 527-537.

Spear, F. S. 1991. On the interpretation of peak metamorphic temperatures in light of garnet diffusion during cooling. Journal of Metamorphic Geology, 9: 379-388. 
Spear, F. S. \& Florence, F. P. 1992. Thermobarometry in granulites: pitfalls and new approaches. Precambrian Research, 55: 209-241.

Spear, F .S., Kohn, M. J., Cheney, J. T. 1999. P-T paths from anatectic pelites. Contributions to Mineralogy and Petrology, 134: 17-32.

Thompson, A. B. 1982. Dehydration melting of pelite rocks and the generation of $\mathrm{H} 2 \mathrm{O}$-undersaturated granitic liquids. American Journal of Science, 282: 1567-1595.

Trompette, R. 1994. Geology of Western Gondwana (2000-500 Ma). Pan-African-Brasiliano aggregation of South America and Africa. A. A. Balkema, Rotterdam, 350 p.

Uhlein, A., Trompette, R., Egydio-Silva, M. 1998. Proterozoic rifting and closure, SE border of the São Francisco Craton, Brazil. Journal of South America Earth Sciences, 11: 191-203.

Vielzeuf, D. \& Schmidt, M. W. 2001. Melting relations in hydrous systems revisited: application to metapelites, metagreywackes and metabasalts. Contributions Mineralogy Petrology, 141: 251-267.
Wedepohl, K. H. 1991. Chemical composition and fractionation of the continental crust. Geologische Rundschau, 80: 207-223.

Wells P. R. A. 1980. Thermal models for magmatic accretion and subsequent metamorphism of continental crust. Earth and Plannetary Scince Letters, 46: 253-265.

White, R. W. \& Powell, R. 2002. Melt loss and the preservation of granulite facies mineral assemblages. Journal of Metamorphic Geology, 20: 621-632.

White, R. W. \& Powell, R. 2010. Retrograde melt-residue interaction and the formation of near-anhydrous leucosomes in migmatites, Journal of Metamorphic Geology, 28: 579-597.

White, R. W., Powell, R., Holland, T. J. B. 2007. Progress relating to calculation of partial melting equilibria for metapelites. Journal of Metamorphic Geology, 25: 511-527.

Arquivo digital disponível on-line no site www.sbgeo.org.br 